\title{
Micromorph brachiopods from the late Asbian (Mississippian, Viséan) from northwest Ireland (Gleniff, County Sligo)
}

\author{
Bernard MotTequin, George SeVAStOPUlo \& ERIC SIMON
}

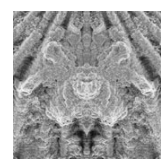

\begin{abstract}
A diverse assemblage of minute brachiopods is reported from the Viséan (late Asbian) Meenymore Formation exposed in the Gleniff outlier, County Sligo, northwest Ireland. The assemblage includes 14 micromorph species and juveniles of larger species, in which spire-bearers (Athyridida, Spiriferida and Spiriferinida) are the most diverse. Most of the species are left in open nomenclature as only few specimens show internal features. However, a new species of the uncommon orthotetide Drahanorhynchus (D. gleniffensis sp. nov.), previously known from the Mississippian of the Czech Republic, Spain and Germany, is described. In addition, the lectotype of the athyridide Hustedia multiplicata (de Koninck, 1887), from the Tournaisian of Tournai (Belgium) is selected and illustrated photographically for the first time. The brachiopods from Gleniff are associated with other small-sized benthic organisms particularly echinoderms and molluscs (gastropods, rostroconchs). The environmental factors, which lead to the small size, are not clearly understood although they probably included a combination of biological (e.g. food supply) and physicochemical (e.g. water oxygenation) parameters. Salinity is probably not implicated because brachiopods and echinoderms are generally stenohaline. - Key words: Carboniferous, Asbian, Meenymore Formation, Brachiopoda, micromorph.
\end{abstract}

Mottequin, B., Sevastopulo, G. \& Simon, E. 2015. Micromorph brachiopods from the late Asbian (Mississippian, Viséan) from northwest Ireland (Gleniff, County Sligo). Bulletin of Geosciences 90(2), 307-330 (15 figures, 1 table). Czech Geological Survey, Prague. ISSN 1214-1119. Manuscript received April 9, 2014; accepted in revised form September 11, 2014; published online February 10, 2015; issued March 23, 2015.

Bernard Mottequin (corresponding author), Royal Belgian Institute of Natural Sciences, O.D. Earth and History of Life, rue Vautier, 29, B 1000 Brussels, Belgium; bmottequin@ naturalsciences.be • George Sevastopulo, Trinity College, Geology Department, College Green, Dublin 2, Ireland; GSVSTPUL@tcd.ie • Eric Simon, Royal Belgian Institute of Natural Sciences, O.D. Earth and History of Life, rue Vautier 29, B 1000 Brussels, Belgium; ericsimon98brach@ gmail.com

Well-preserved brachiopod faunas containing small individuals have been reported from several occurrences in Mississippian limestones of Western Europe (e.g. Brunton 1966a, 1968, 1984; Brunton \& Champion 1974; Bassett \& Bryant 1993; Morris 1994; Martínez-Chacón 1997) and elsewhere in the world (e.g. Baliński \& Sun 2008; Sun \& Baliński 2008, 2011). The present paper is concerned with micromorph brachiopods recovered from the Viséan Meenymore Formation in northwest Ireland (Figs 1, 2). This study complements those of Brunton (1966a, 1968, 1984) and Harper \& Jeffrey (1996a, b) on Irish Viséan brachiopod faunas.

\section{Geological setting}

The Carboniferous rocks adjoining Donegal Bay, northwest Ireland (Fig. 1), have been described by George \& Oswald (1957), Oswald (1955) and, in summary form, by
Sevastopulo \& Wyse Jackson (2009). The stratigraphical age of the rocks in the area shown on the map in Fig. 1 extends from the early to late Viséan (Fig. 2). The younger part of the succession (Benbulben Shale Formation, Glencar Limestone Formation and Dartry Limestone Formation, all assigned to the Tyrone Group) forms high ground, including the mountains of Ben Bulben and Slievemore, in the southeast quarter of the map. Oswald (1955) described two formations, in ascending order the Glenade Shale and Glenade Sandstone, which form a cap to the Dartry Limestone in this region. The former, which is extremely poorly exposed in the area shown in Fig. 1, has been renamed the Meenymore Formation (Brandon 1977; Fig. 2) and is the oldest formation of the Leitrim Group.

During mapping of the area above Gleniff (Fig. 1), an outlier of weathered clay with nodular limestone, referred to below as the Gleniff outlier, was discovered. The extent of the outlier is difficult to establish because of poor exposure except where a track from Gleniff to the abandoned 


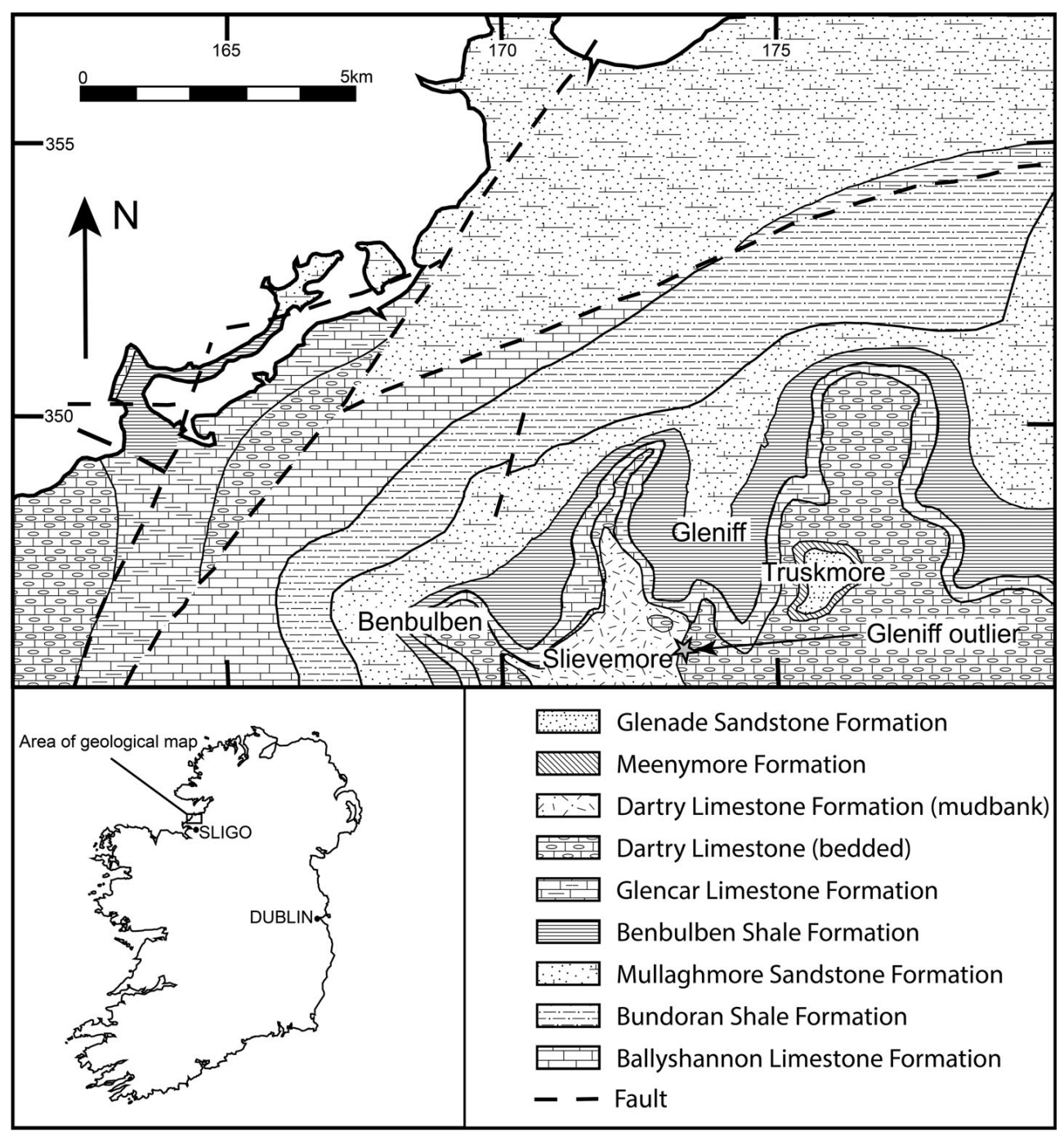

Figure 1. Regional geology of northwest County Sligo showing the location of the Gleniff outlier. Based on MacDermot et al. (1996).

baryte mine on Slievemore, County Sligo (Figs 1, 3) cuts through it for approximately $30 \mathrm{~m}$. The rocks, even though they are weathered are clearly lithologically distinct from the surrounding cherty limestones of the Dartry Limestone Formation, which also are in places thoroughly weathered to chert rubble set in clay. The lithology and the fauna, which includes the ammonoid Nomismoceras sp., is consistent with that of the Meenymore Formation, which is stratigraphically younger than the Dartry Limestone. The geological relationships strongly suggest that the outlier is allochthonous: the Dartry Limestone Formation is found up to $\mathrm{ca} 70 \mathrm{~m}$ topographically higher along the track and elsewhere above the outlier. The most probable explanation of the present position of the outlier, topographically below the top of the Dartry Limestone Formation, is that it is a raft of the Meenymore Formation, which has arrived in its present position as a result of karstic solution collapse. This is consistent with the presence of several caves dissected by the cliffs in the Dartry Limestone Formation and numerous boulders of sandstone, identified as derived from the Glenade Sandstone Formation, at topographic levels similar to and below the Gleniff outlier.

\section{Material and methods}

The brachiopods described here were obtained by surface collecting and disaggregation of bulk samples from weathered shale and limestone exposed on both sides of the track (Fig. 3) (collecting locality: Irish Grid Reference $173390345759)$. Note that this sampling method has probably lead to the amalgamation of the faunas of several beds and it is not possible to determine precisely the real thickness of the succession sampled. To disaggregate the clay, bulk samples were simmered in a weak solution of the surfactant Quaternary O (Zingula 1968); the resulting sludge was sieved and dried and the fossils picked using a stereomicroscope. All these specimens are housed at the Geological Museum, Trinity College, Dublin (TCD). Additional material from the de Koninck collection, curated at 


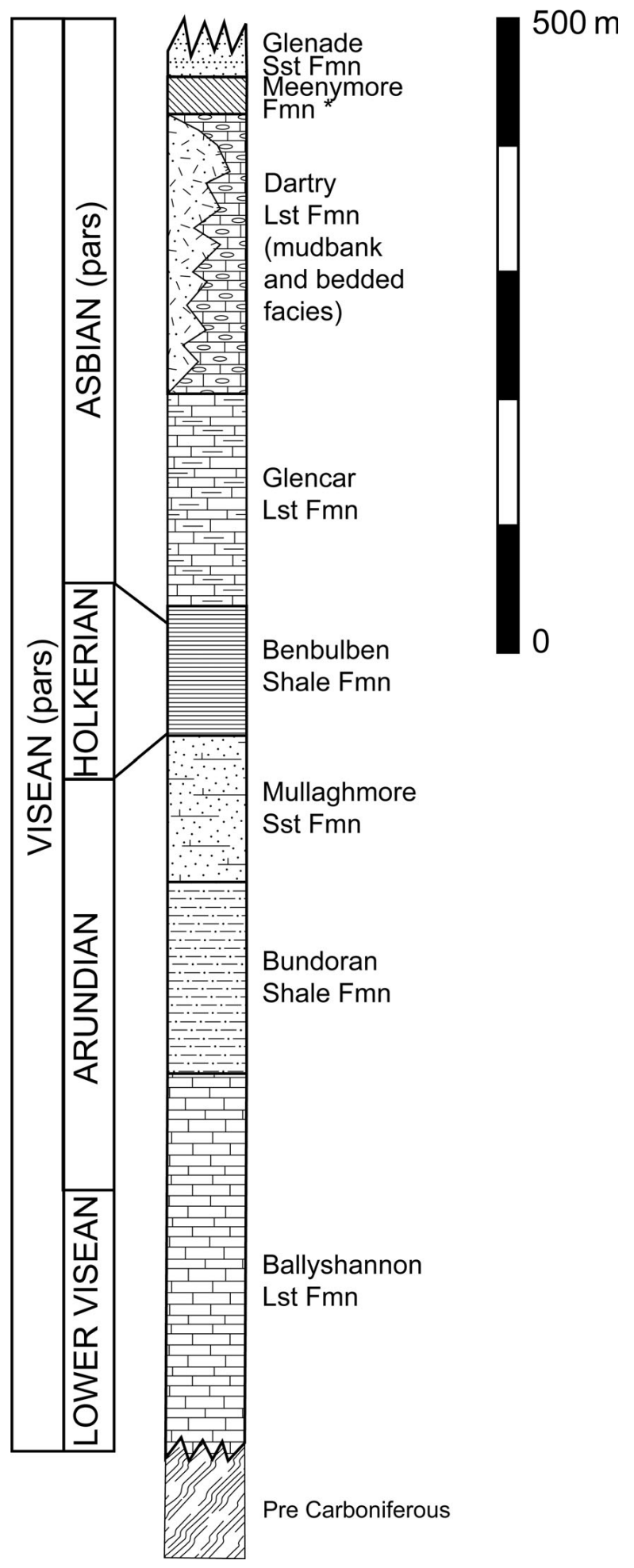

Figure 2. Regional stratigraphy of northwest County Sligo, showing the stratigraphical position of the Meenymore Formation. The asterisk denotes the horizon from which the brachiopods were collected.

the Royal Belgian Institute of natural Sciences in Brussels (IRScNB), is also illustrated.

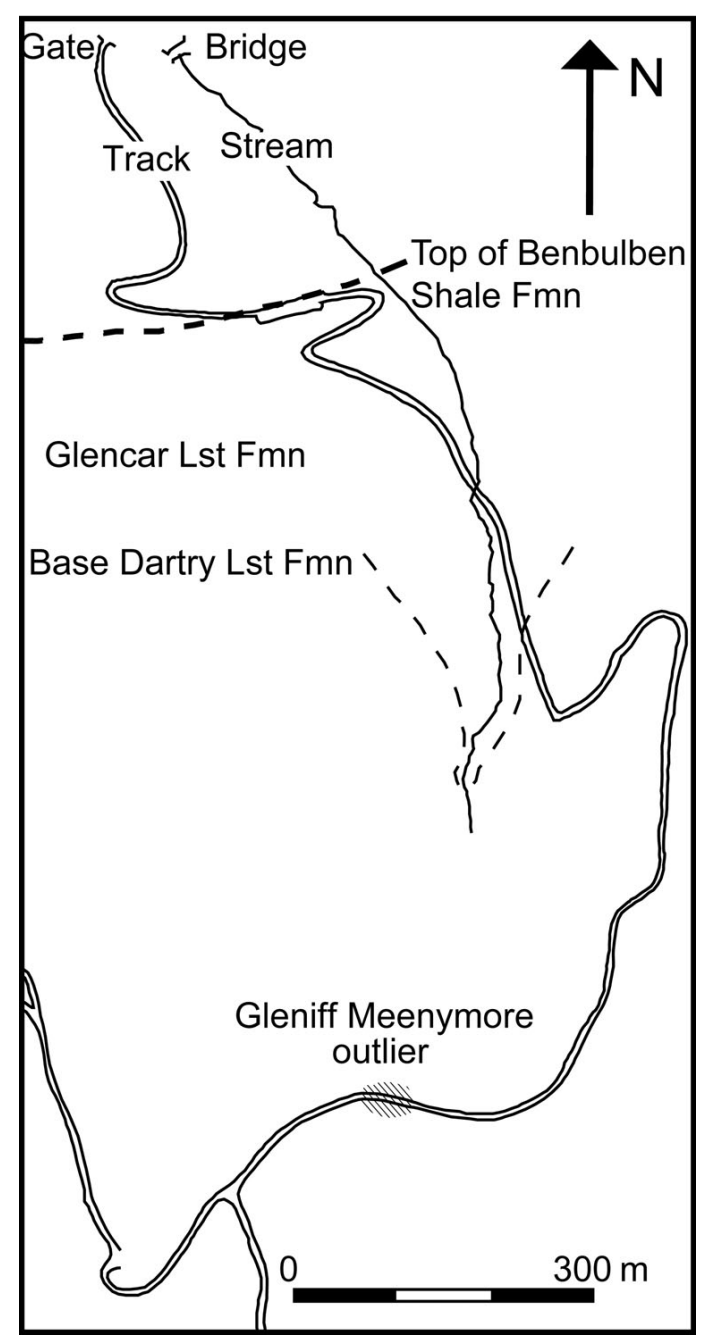

Figure 3. Sketch map of the location of the Gleniff Meenymore outlier (Irish Grid Reference 173390 345759) showing the access from the gate on the Gleniff Horseshoe road. Modified from a sketch map prepared by the late Conor MacDermot, Geological Survey of Ireland.

Abbreviations. - Hi - height of the ventral interarea; $\mathrm{L}$ - length of the shell; $\mathrm{Td}$ - thickness of the dorsal valve; Tv - thickness of the ventral valve; $\mathrm{W}$ - width of the shell; $\mathrm{Wi}$ - width of the interarea; Ws - width of the sulcus.

\section{Systematic palaeontology}

The supraspecific classifications follow Holmer \& Popov (2000) for Order Lingulida, Rachebœuf (2000) for Suborder Chonetidina, Brunton et al. (2000) for Suborder Productidina, Williams \& Brunton (2000) for Suborder Orthotetidina, Williams \& Harper (2000) for Order Orthida, Savage et al. (2002) for Order Rhynchonellida, Alvarez \& Rong (2002) for Order Athyridida, Carter et al. (2006) for Order Spiriferida, Carter \& Johnson (2006) for Order Spiriferinida, and Lee et al. (2006) for Order Terebratulida. 
Subphylum Linguliformea Williams et al., 1996

Class Lingulata Gorjansky \& Popov, 1985

Order Lingulida Waagen, 1885

Superfamily Discinoidea Gray, 1840

Family Discinidae Gray, 1840

\section{?Genus Oehlertella Hall \& Clarke, 1890}

Type species. - Discina pleurites Meek, 1875; from the Cuyahoga Formation, Tournaisian, Ohio, USA.

\section{Oehlertella? sp. indet.}

Figure 4A-E

Material. - One dorsal valve (TCD.60901).

Remarks. - This incomplete single, small-sized ( ca $1.5 \mathrm{~mm}$ in width), convex, subcircular (with flattened posterior margin) dorsal valve is characterized by the submarginal position of its apex and is covered by numerous fine growth lines (Fig. 4E). The particular position of the apex suggests a tentative assignment to the poorly known genus Oehlertella Hall \& Clarke (1890) rather than to the long ranging discinid Orbiculoidea d'Orbigny, 1847. Nevertheless, ventral valves are required to reach a more confident identification notably based on the position and form of the pedicle track, as the dorsal valves of the discinid genera mentioned above, but also that of Lingulodiscina Whitfield, 1890 (doubtfully reported in the Carboniferous by Holmer \& Popov 2000), are relatively similar.

Order Productida Sarycheva \& Sokolskaya, 1959

Surborder Chonetidina Muir-Wood, 1955

Superfamily Chonetoidea Bronn, 1862

Family Anopliidae Muir-Wood, 1962

Subfamily Caenanopliinae Archbold, 1980

\section{Genus Globosochonetes Brunton, 1968}

Type species. - Globosochonetes parseptus Brunton, 1968; from the Viséan (Asbian) Upper Glencar Limestone Formation, County Fermanagh, Northern Ireland.

\section{Globosochonetes sp. indet.}

Figure 4F-AA

Material. - Ten articulated specimens, six ventral and nine dorsal valves (TCD.60902-60908).

Description. - Shell small-sized (ca $5 \mathrm{~mm}$ in width), clearly wider than long, transverse in outline, strongly concavoconvex, greatest width probably at the hinge line (none of the specimens is complete); hinge line straight; anterior commis- sure clearly uniplicate. Ventral valve with median part inflated like a round-topped fold; umbo prominent; beak straight; interarea low, flat but slightly concave near beak; delthyrium open (no trace of pseudodeltidium possibly as a result of poor preservation). Dorsal valve strongly concave; interarea linear, hypercline, flat; notothyrium concealed by convex chilidium.

Only one pair of broken spines observed only in a single specimen (Fig. 4L, N). Ribs rounded, arising close to umbones and increasing by rare intercalations and bifurcation, those in ventral central part being parallel; microlines numerous, regularly spaced ( $c a 35 \mu \mathrm{m}$ between each line); 26 ribs in the largest specimen (5-6 ribs per $\mathrm{mm}$ at the anterior margin); intercostal grooves similar to ribs.

Ventral interior unknown. Dorsal valve interior (Fig. 4Q-AA) with long, narrow inner socket ridge, almost parallel to hinge line, widely divergent anteriorly $\left(159^{\circ}\right.$, $\mathrm{n}=1$ ) and supported small, posteroventrally oriented cardinal process, cardinal process small but distinct (Fig. 4S-T, $\mathrm{X}, \mathrm{AA})$; anderidia thin, short, anteriorly divergent at $110^{\circ}$ $(\mathrm{n}=1)$; accessory septa very long, blade-like, anteriorly divergent at $16-24^{\circ}(n=2)$.

Remarks. - These transverse anopliides indubitably belong to Globosochonetes and may represent a new species characterized by its transverse outline, its ventral valve strongly inflated in its middle part, its low number of spines, and its ribbing, but additional material is required to reach a precise specific identification. Globosochonetes sp. indet. differs from G. parseptus Brunton, 1968, from the Upper Glencar Limestone Formation (Asbian) of County Fermanagh, notably by its more transverse outline and its ventral valve with inflated median part, which is distinct from the lateral. Globosochonetes sp. indet. is closely similar to G. waldenburgianus (Paeckelmann, 1930), first described from the German Upper Kulm facies (Viséan, Saxony) and also reported in the Bashkirian and Moscovian of the Spanish Cantabrian Mountains (Martínez Chacón 1979, Río García 2002), in its size, its outline and its inflated ventral valve, but it can be distinguished from the latter by its lateral ribs that are not divided or only exceptionally so.

Family Rugosochonetidae Muir-Wood, 1962

Subfamily Rugosochonetinae Muir-Wood, 1962

\section{Genus Rugosochonetes Sokolskaya, 1950}

Type species. - Orthis hardrensis Phillips, 1841; from the Viséan (Brigantian) of Hardrow, Yorkshire, England.

Rugosochonetes? sp. indet.

Figure 4BB-EE

Material. - Two dorsal valves (TCD.60909-60910). 


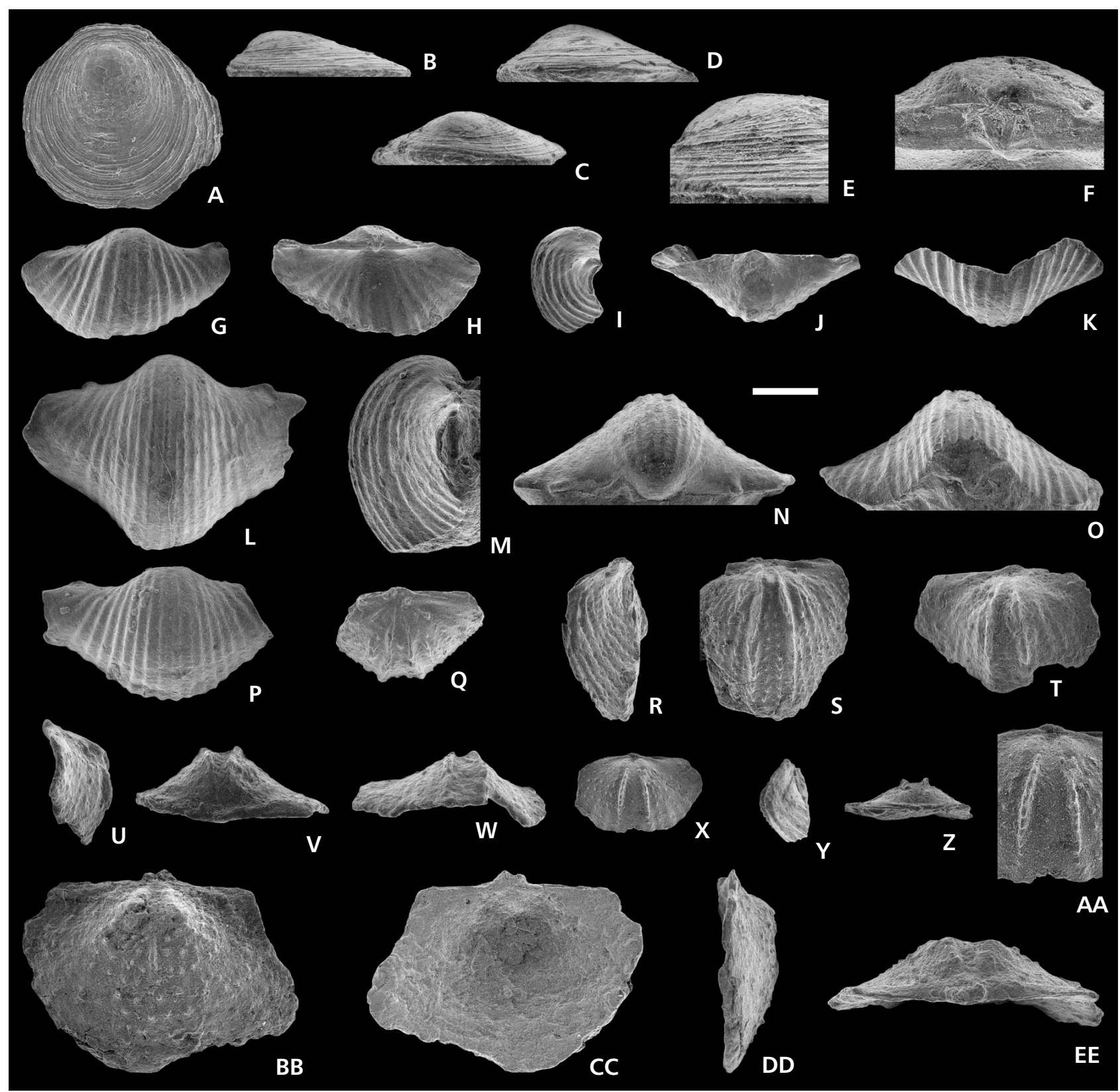

Figure 4. A-E-Oehlertella? sp. indet., incomplete dorsal valve (TCD.60901) in dorsal, lateral, oblique posterior and anterior views and close-up of the growth lamellae. $\bullet \mathrm{F}-\mathrm{AA}-$ Globosochonetes sp. indet. $\bullet \mathrm{F}-\mathrm{K}$ - almost complete articulated specimen (TCD.60902) with close-up of the central part of the ventral and dorsal inteareas showing the delthyrium, chilidium and both lobes of the cardinal process and in ventral, dorsal, lateral, posterior and anterior views. $\bullet$ L-O - almost complete ventral valve (TCD.60903) in ventral, lateral, posterior and anterior views. $\bullet$ P - incomplete ventral valve (TCD.60904). - Q-S - incomplete dorsal interior (TCD.60905) in posterior, lateral and ventral views. • T-W - incomplete dorsal interior (TCD.60906) in ventral, lateral, posterior and anterior views. $\bullet$ X-AA - incomplete juvenile dorsal interior (TCD.60907) in dorsal, lateral and posterior views and close-up showing the blade-shaped accessory septa, the anderidia, and the cardinal process pit. $\bullet$ BB-EE - Rugosochonetes sp. indet. Dorsal valve (TCD.60909) in internal, external, lateral and posterior views. All the specimens are from the Meenymore Formation, Gleniff. Scale bar: $1 \mathrm{~mm}$ for all, except A-D and $\mathrm{AA}(500 \mu \mathrm{m}), \mathrm{E}(200 \mu \mathrm{m})$ and $\mathrm{F}(250 \mu \mathrm{m})$.

Remarks. - These strongly concave dorsal valves are internally characterized by small cardinal lobes fused medianly, a low and short median septum and strong, anteriorly divergent anderidia ( $\left.44^{\circ}[\mathrm{n}=1]\right)$. These features suggest a possible assignment to Rugosochonetes in spite of the lack of knowledge about the ornamentation as a result of very poor preservation. 


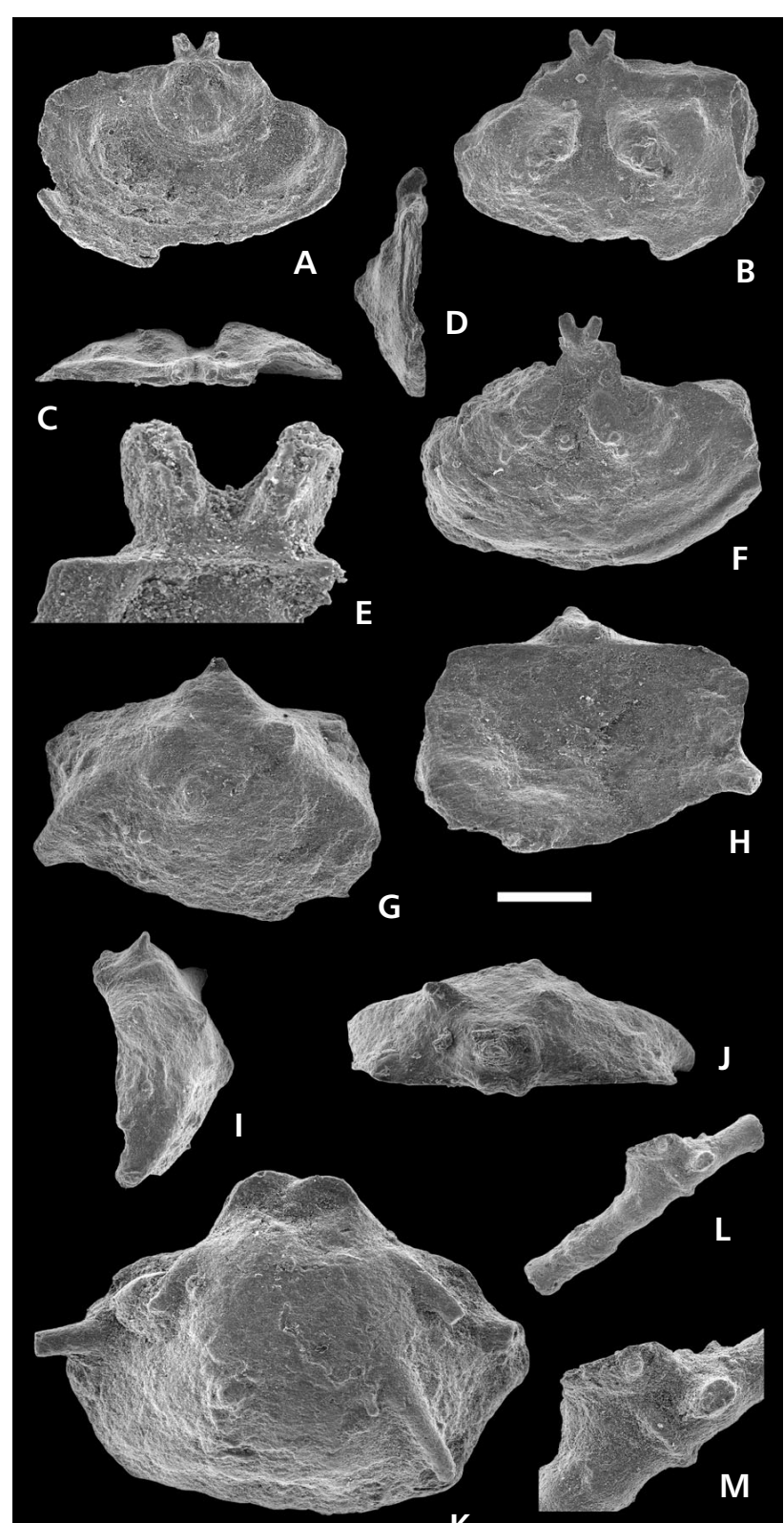

K

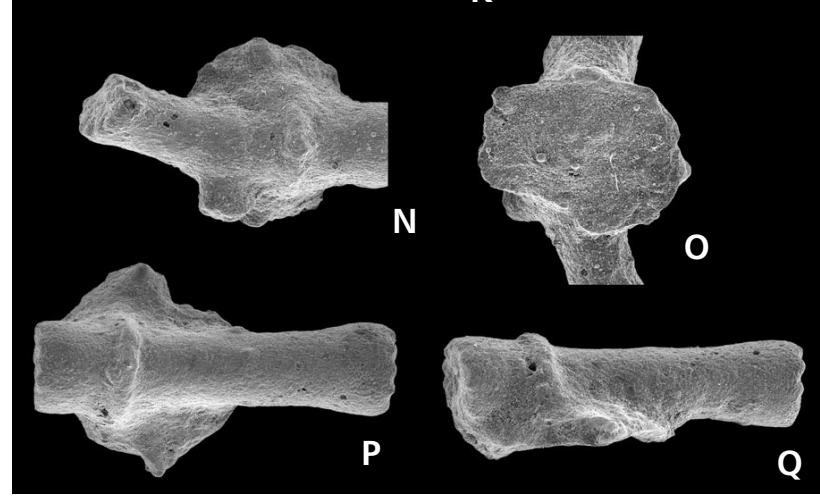

Figure 5. Argentiproductus cf. margaritaceus (Phillips, 1836) from the Meenymore Formation, Gleniff. • A-D - almost complete dorsal valve (TCD.60911) in external, internal, posterior and lateral views. $\bullet$ E, F - incomplete dorsal valve (TCD.60912) with close-up of the cardinal process
Suborder Productidina Waagen, 1883

Superfamily Productoidea Gray, 1840

Family Productellidae Schuchert, 1929

Subfamily Productininae Muir-Wood \& Cooper, 1960

\section{Genus Argentiproductus Cooper \& Muir-Wood, 1951}

Type species. - Producta margaritacea Phillips, 1836; from the Viséan of County Fermanagh, Ireland.

\section{Argentiproductus cf. margaritaceus (Phillips, 1836)} Figure 5

Material. - Four ventral and three dorsal valves (TCD.60911-60917).

Description. - Shell concavo-convex, wider than long, rounded subpentagonal in outline, widest at midlength; anterior commissure rectimarginate; anterior margin rounded in ventral view. Ventral valve moderately convex, with pedicle sheath. Dorsal valve slightly concave.

Spines prostrate to recumbent on flanks, erect on umbo (clasping spines).

Ventral interior unknown. Interior of dorsal valve (Fig. 5A-F) with cardinal process bifid with lobes dorso-posteriorly incised and projecting well beyond the hinge line; adductor scars rounded trigonal in outline; no myophragm; cardinal ridges diverging from the cardinal process base at low angle from hinge line; rugae traces visible on the internal surface of the valve.

Remarks. - These juvenile specimens are tentatively assigned to the type species of Argentiproductus due to their close similarity to the material from the Upper Glencar Formation of Co. Fermanagh illustrated by Brunton (1966a) and Brunton et al. (1993). The doubt is due to the absence of larger specimens that would have allowed observation of the characteristic ornamentation. On the basis of exceptionally well-preserved material from the Tournaisian of South China, Sun \& Baliński (2008) discussed exhaustively the mode of attachment of juveniles of $A$. margaritaceus to the substrate. Two poorly preserved and minute ventral valves, which are attached to crinoid ossicles by clasping spines, complement the available larger ventral valve (Fig. $5 \mathrm{~L}-\mathrm{Q})$.

grooved lobes (dorsal side) and in internal view. • G-J - ventral valve (TCD.60913) in ventral, dorsal, slightly oblique lateral and posterior views. • K - ventral valve (TCD.60914). • L-O - fragmentary ventral valve (TCD.60915) attached to crinoid ossicle by clasping spines in lateral view, close-ups (showing the thin clasping spines) and in dorsal view. - P-Q - incomplete ventral valve (TCD. 60916) attached to crinoid ossicle in posterior and lateral views. Scale bar: $500 \mu \mathrm{m}$ for all, except E $(100 \mu \mathrm{m})$ and $\mathrm{L}(1 \mathrm{~mm})$. 
Order Orthotetida Waagen, 1884

Suborder Orthotetidina Waagen, 1884

Superfamily Orthotetoidea Waagen, 1884

Family Schuchertellidae Williams, 1953

Subfamily Streptorhynchinae Stehli, 1954

\section{Genus Drahanorhynchus Havlíček, 1967}

Type species. - Drahanorhynchus drahanicus Havlíček, 1967, from the Březina Formation, Viséan, Czech Republic.

Drahanorhynchus gleniffensis sp. nov. Figures 6, 7, Table 1

Type. - Holotype (TCD.60926), an incomplete dorsal valve (Figs $6 \mathrm{X}-\mathrm{Z}, 7$ ).

Type horizon and locality. - Meenymore Formation (Viséan, late Asbian), Gleniff (Irish Grid Reference 173390 345759).

Material. - Fifty-five ventral and nine dorsal valves (TCD.60918-60930).

Etymology. - From Gleniff (County Sligo), the type locality.

Diagnosis. - A species of Drahanorhynchus with shell wider than long (up to $c a 3.5 \mathrm{~mm}$ in width), planoconvex and semi-circular in outline. Faint median depressions developed on both valves. Six rounded ribs per $1 \mathrm{~mm}$ at ventral anterior margin. Dorsal ventral muscle field well defined, extending up to about half of the valve length, diamond-shaped; myophragm flanked by up to 4 pairs of radiating septa in these adult specimens.

Description. - Shell small-sized (up to $c a 3.5 \mathrm{~mm}$ in width), wider than long (W/L: $1.33-1.73$ [n = 6]), planoconvex, semi-circular in outline; hinge line straight narrower than the greatest width (Wi/W: 0.65-0.89 [n = 8]); anterior margin straight in ventral view; anterior commissure rectimarginate or undulose. Ventral valve more or less subconical (especially in juveniles; Fig. 6C, T) or convex, with a faint depression developed in its anterior part; beak straight; interarea of variable height $(\mathrm{Hi} / \mathrm{Wi}$ : $0.21-0.5$ $[n=5])$, flat, catacline to apsacline; delthyrium closed by strongly convex and stout pseudodeltidium (Fig. 6M, N) bearing some growth lines; attachment cicatrix in some specimens with koskinoid perforations (Fig. 6I); supraapical foramen only seen in juveniles (Fig. 6I, J, O, S) and of clearly larger diameter than that of the koskinoid perforations. Dorsal valve bearing a faint depression in its anterior part; chilidium vestigial.
Table 1. Measurements of Drahanorhynchus gleniffensis sp. nov. (in $\mathrm{mm}$ ). Brackets indicate estimation. Abbreviations: Hi - height of ventral interarea; Ld - length of dorsal valve; $\mathrm{Lv}$ - length of ventral valve; $\mathrm{TV}$ - thickness of ventral valve; $\mathrm{W}$ - width of shell; Wi - width of interarea.

\begin{tabular}{lcccccc}
\hline TCD & W & Wi & Lv & Ld & Tv & Hi \\
\hline 60918 & 3.5 & 3.1 & 2.4 & & 1.5 & 1.3 \\
60920 & 1.8 & $(0.7)$ & 1.2 & & $/$ & $/$ \\
60921 & 2 & 1.3 & 1.5 & & 0.5 & 0.3 \\
60922 & 1.6 & 1.4 & 1 & & 0.5 & 0.3 \\
60923 & 1.9 & 1.6 & 1.1 & & 0.7 & 0.5 \\
60924 & 1.6 & 1.4 & 1.1 & & 0.8 & 0.7 \\
60926 & $(3.6)$ & $(2.4)$ & & 2.5 & & \\
60927 & 2.1 & $/$ & & 1.5 & & \\
60928 & 2 & 1.6 & & 1.5 & & \\
\hline
\end{tabular}

Ornamentation multicostellate (ribs increasing by intercalation in dorsal and ventral valves, rare bifurcations in ventral valve); 6 rounded ribs per $1 \mathrm{~mm}$ at ventral anterior margin, separated by similar intercostal grooves; microgrowth lines abundant (5-6 per $0.1 \mathrm{~mm}$ ), some of them thickened; spines projecting from rib crest preserved in several specimens (Fig. 6V, W).

Ventral interior with small teeth rectangular in outline (Fig. 6M, N). Dorsal valve interior (Figs 6Y, 6AA-CC, 7B) with bilobed cardinal process with small lobes posteriorly oriented; dental sockets small, open postero-laterally; socket ridges strongly diverging from hinge line and fused to the cardinal process; muscle field well-defined in adult shells extending up to about half of the valve length, diamond-shaped; myophragm flanked by up to 4 pairs of radiating septa in adult specimens (not developed in juveniles).

Remarks. - The genus Drahanorhynchus was originally described from the Viséan of Central Europe (Czech Republic) by Havlíček (1967). Its diagnosis was revised by Martínez Chacón \& Winkler Prins (1977) and our material conforms to it exactly. To our knowledge, only steinkerns have been illustrated in the literature and the specimens under discussion here are the first with preserved shell to be illustrated, showing notably the microspinous ornament previously reported by various authors (see references herein) and the presence of a supra-apical foramen similar to that illustrated by Brunton \& Cocks (1996, fig. 1.6) in a Silurian strophomenide ("Leptaena"). This particular structure was lost early during the ontogeny in Orthotetidina (Williams \& Brunton 1993, Brunton \& Cocks 1996), but demonstrates that larval stages of this species were able to fix on a substrate with their pedicle before cementing on it during late stages. Moreover, the exfoliated parts of the inner surface of the dorsal valve illustrated in Fig. 6CC distinctly shows numerous dimples, which correspond 
to radially distributed deflections of the laminae pointing outwardly. They correspond to the "closely crowded pits" reported by Havlíček (1967) on the internal moulds of Drahanorhynchus drahanicus Havlíček, 1967. Note that, due to the preservation, it is not possible to see if the lobes are bilobed posteriorly or not. Besides its presence in Central Europe, Drahanorhynchus has been reported from the Tournaisian-Bashkirian of Spain (Martínez Chacón \& Winkler Prins 1977, Amler \& Winkler Prins 1999, Martínez Chacón et al. 2003) and from the Tournaisian-Viséan (Culm facies) of Germany (e.g. Martínez Chacón \& Winkler Prins 1977, Martínez Chacón et al. 2003).

Drahanorhynchus gleniffensis sp. nov. differs from D. drahanicus Havlíček, 1967 and D. paeckelmanni (Gallwitz, 1932) notably in its smaller size and its more divergent socket ridges. From Drahanorhynchus cantabricus Martínez Chacón \& Winkler Prins, 1977, the new species is distinguished notably by its smaller size and the presence of faint ventral and dorsal median depressions usually developed in the largest specimens.

Class Rhynchonellata Williams et al., 1996

Order Orthida Schuchert and Cooper, 1932

Suborder Dalmanellidina Moore, 1952

Superfamily Enteletoidea Waagen, 1884

Family Schizophoriidae Schuchert \& LeVene, 1929

\section{Genus Schizophoria King, 1850}

Type species. - Conchyliolithus (Anomites) resupinata Martin, 1809; from the Viséan of Dovedale, Derbyshire, England.

\section{Schizophoria sp. indet.}

Figure 8A-E

Material. - Three ventral valves (TCD.60931-60932).

Remarks. - These wider than long (W/L: $1.36[\mathrm{n}=1]$ ) ventral valves (up to $1.95 \mathrm{~mm}$ in width) display the following characters: hinge line straight, narrower than the greatest width (Wi/W: $0.52[\mathrm{n}=1]$ ), interarea moderately high (for the size of the specimens!), relatively flat to concave, ortho-apsacline; delthyrium large, open (mar- gin angle: $39-44^{\circ} ; \mathrm{n}=3$ ); ornamentation multicostellate (4-5 ribs per $0.5 \mathrm{~mm}$ on the anterolateral margin); teeth strong (muscular field unobserved). Although further material is required for a more exact identification, our material is externally closer to juveniles of Schizophoria resupinata dorsosinuata Demanet, 1934 illustrated by Brunton (1968, pl. 2, figs 22-36) from the Upper Glencar Formation in terms of ventral valve shape and interarea rather than to those assigned to Rhipidomella michelini (Léveillé, 1835) by Brunton (1968, pl. 3, figs 21, 22, $24,25)$ from the same lithostratigraphic unit. They are thus identified as Schizophoria sp. in the absence of dorsal valves.

Order Rhynchonellida Kuhn, 1949

Superfamily Rhynchoporoidea Muir-Wood, 1955

Family Rhynchoporidae Muir-Wood, 1955

Subfamily Tretorhynchinae Savage, 2002

\section{Genus Tretorhynchia Brunton, 1971}

Type species. - Terebratula trilatera de Koninck, 1843; from the upper part of the Visé Formation, Viséan (Arundian), Visé, Belgium.

\section{Tretorhynchia cf. trilatera (de Koninck, 1843)} Figure $8 \mathrm{~F}-\mathrm{O}$

Material. - Twenty-one articulated specimen (TCD.60933 to 60935).

Description. - Shell subtriangular in outline, small-sized (up to $2.9 \mathrm{~mm}$ in width), longer than wide (W/L: 0.87-0.89 $[\mathrm{n}=2]$ ), aequibiconvex, widest in anterior third part of shell; anterior commissure rectimarginate; anterior margin strongly emarginate in ventral view. Ventral valve with median groove; beak suberect; delthyrium open. Dorsal valve with well-developed median groove.

At least 14 simple rounded ribs (the preservation is not sufficiently good to make an exact count) separated by similar intercostal grooves.

Internal morphology unknown; some exfoliated shells display endopunctae.

Remarks. - Our material is tentatively assigned to Tretorhynchia trilatera as the specimens are externally very

Figure 6. Drahanorhynchus gleniffensis sp. nov. Meenymore Formation, Gleniff. • A-E - ventral valve (TCD.60918) in ventral, dorsal, lateral, posterior and anterior views. $\bullet \mathrm{F}-$ ventral valve (TCD.60919). $\bullet \mathrm{G}-\mathrm{I}-$ ventral valve (TCD.60920) in ventral and posterior views and close-up of the umbo showing koskinoid structure. • J-N - ventral valve (TCD.60921) in ventral, dorsal and posterior views and close-ups showing the strongly convex pseudodeltidium and the small teeth. $\bullet \mathrm{O}, \mathrm{P}-$ ventral valve (TCD.60922) in ventral and posterior views. $\bullet$ Q, R - incomplete ventral valve (TCD.60923) in ventral and posterior views. $\bullet$ S-U - ventral valve (TCD.60924) in ventral, lateral and posterior views. $\bullet$ V, W- ventral valve (TCD.60925) in oblique ven- 


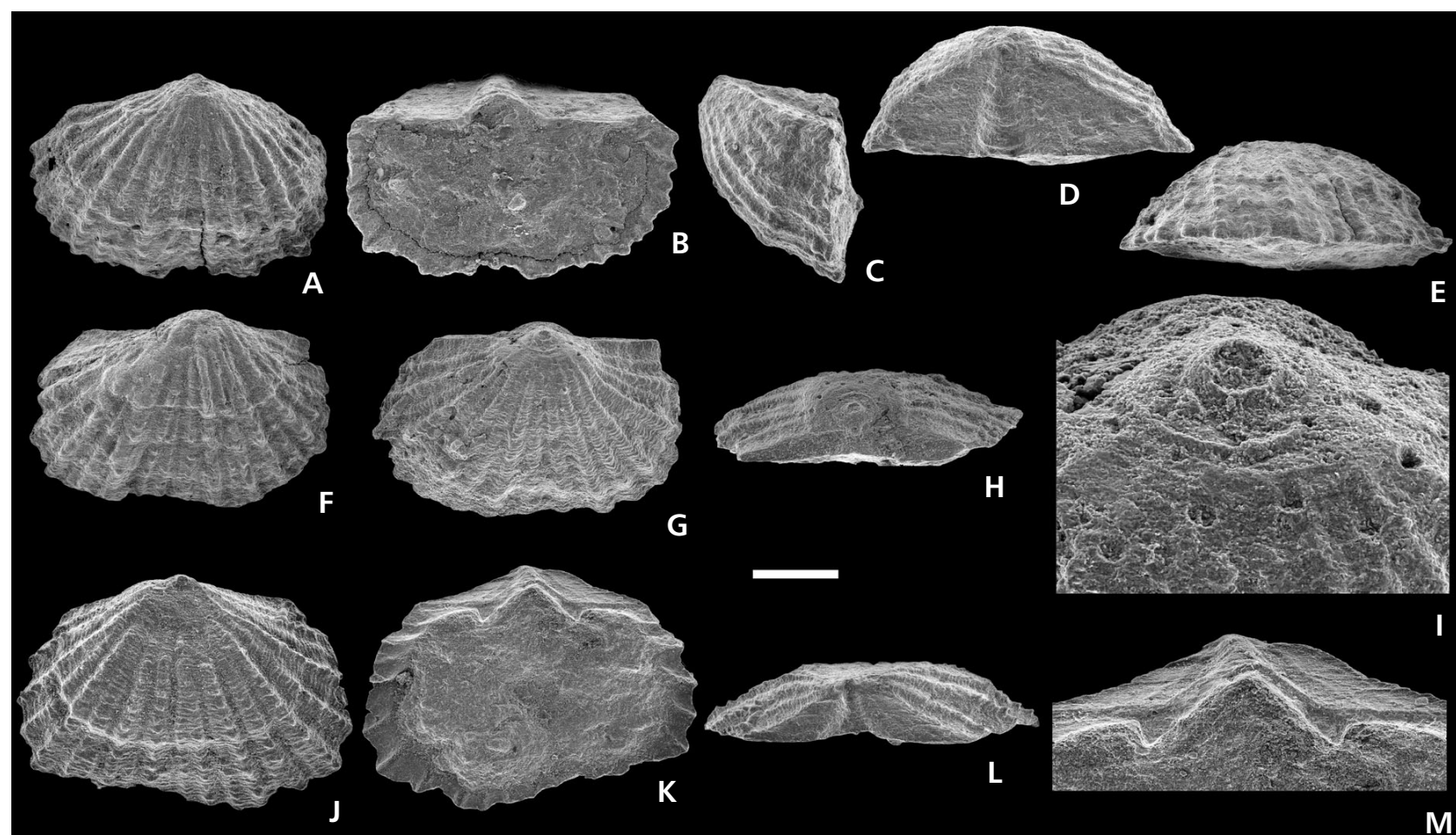

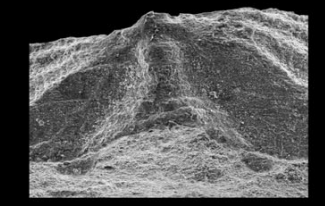

N

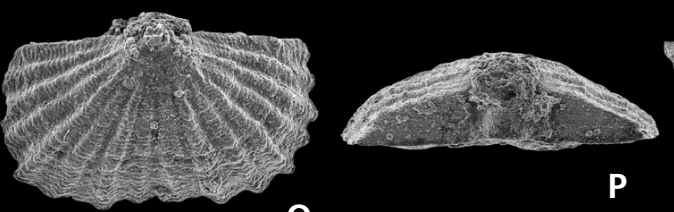

0
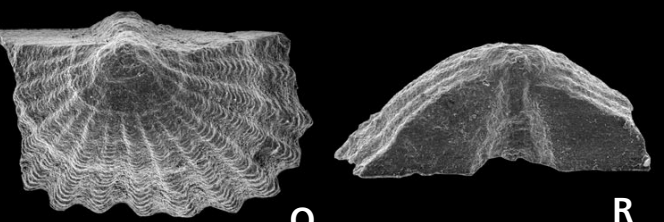

Q
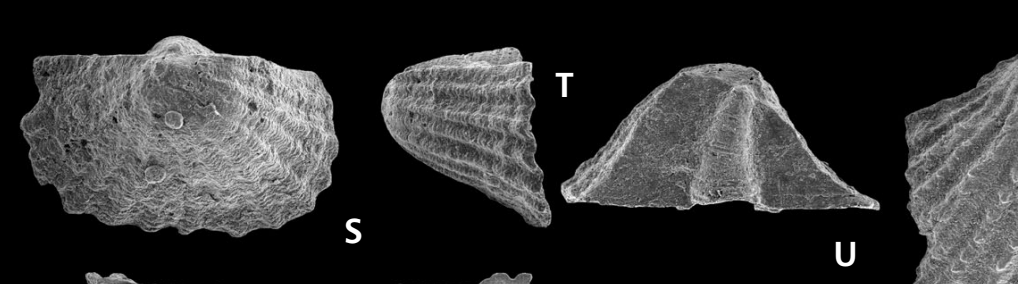

- $2 x+5$
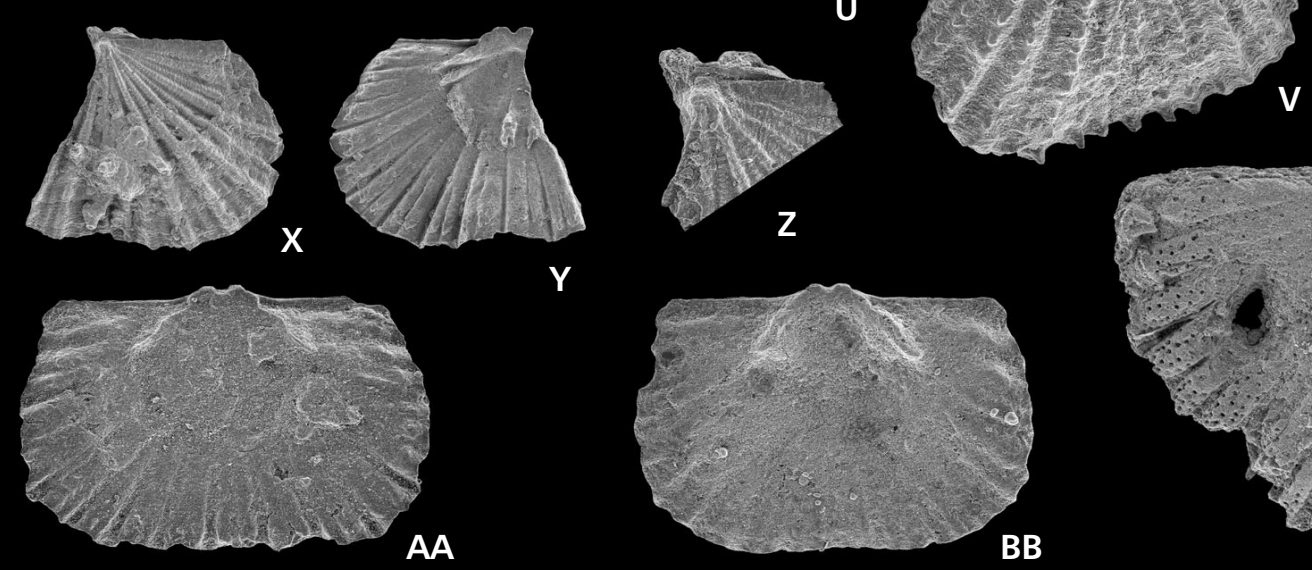

tral view showing preserved spines close to the anterior margin and close-up in lateral view. $\bullet \mathrm{X}-\mathrm{Z}$ - incomplete dorsal valve incrusted by enigmatic organism (holotype, TCD.60926, see also Fig. 7) in external and internal views and close-up of the vestigial chilidium and the cardinal process lobes. - AA - juvenile dorsal interior (TCD.60927). • BB - juvenile dorsal interior (TCD.60928). • CC - incomplete dorsal interior (TCD.60929). Scale bar: $500 \mu \mathrm{m}$ for all, except A-F and X-Y (1 mm), I (100 $\mu \mathrm{m}), \mathrm{M}-\mathrm{N}(250 \mu \mathrm{m}), \mathrm{W}(200 \mu \mathrm{m})$ and Z $(400 \mu \mathrm{m})$. 


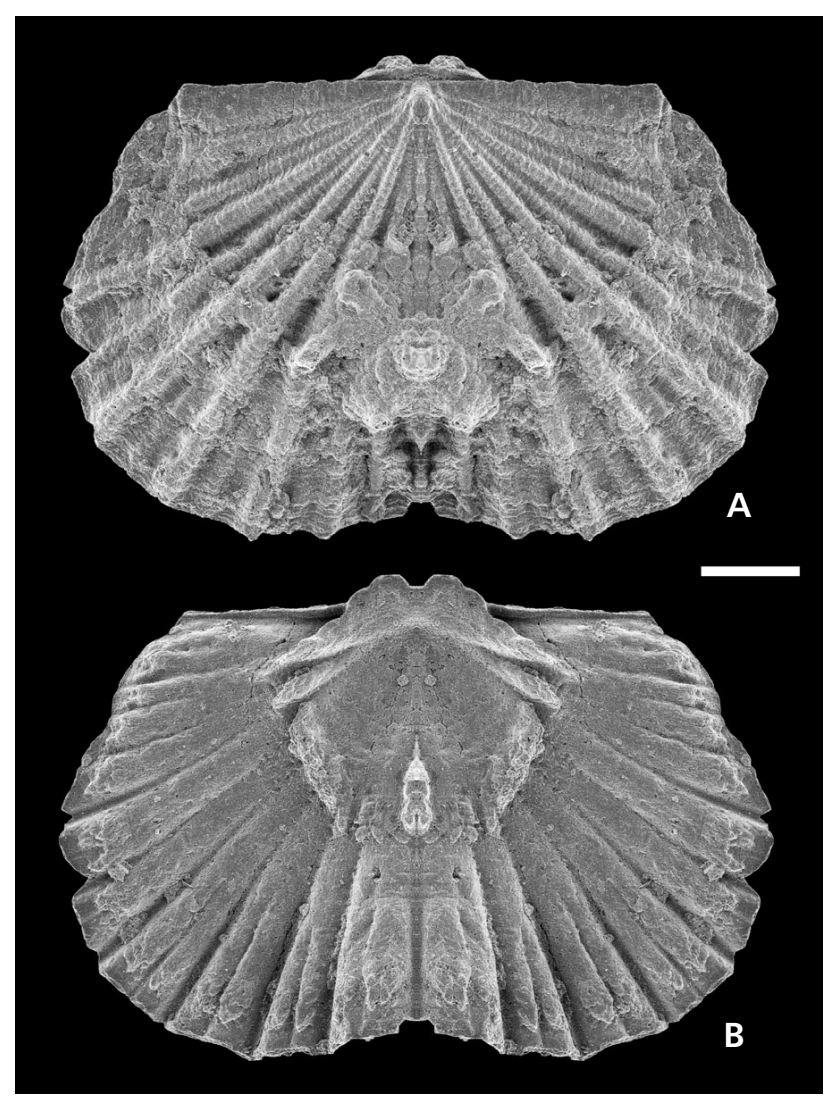

Figure 7. Drahanorhynchus gleniffensis sp. nov. Meenymore Formation, Gleniff. Slightly strained reconstruction of the holotype (TCD.60926; see Fig. 6X-Z for comparison), i.e. an incomplete dorsal valve in external and internal views. Scale bar: $500 \mu \mathrm{m}$.

close to juveniles from the Asbian Upper Glencar Formation of County Fermanagh assigned to Tretorhynchia trilatera by Brunton (1984, figs 16, 17). However, no adult was recovered from Gleniff and the internal features are not exposed. The types of Tretorhynchia trilatera are from Visé (southern Belgium) and were recovered from the Visé Formation ranging from the late Tournaisian to the late $\mathrm{Vi}$ séan (although they have not been collected from the Livian). Most of the fossils from Visé have been recovered from quarry F-G (e.g. Demanet 1958, Pirlet 1967, Poty 1982, Hance et al. 2006), where exposures still exist although the rocks are unfortunately inaccessible. The rocks are massive algal and bioclastic boundstones that form buildups rich in brachiopods of late Asbian age (Warnantian; e.g. Hance et al. 2006). This is of course not the case for all the brachiopods present in the old "Visé collections" disseminated in numerous museums through the world but it is likely to be the case for this rhynchonellide species due its state of preservation and coloration (see discussion in Demanet 1958). Besides its presence in County Fermanagh (Brunton 1984), T. trilatera was reported in mid to late Viséan strata by Brunton (1971) and Brunton \& Tilsley (1991). Note that Pakhnevich (2013) recently proposed to

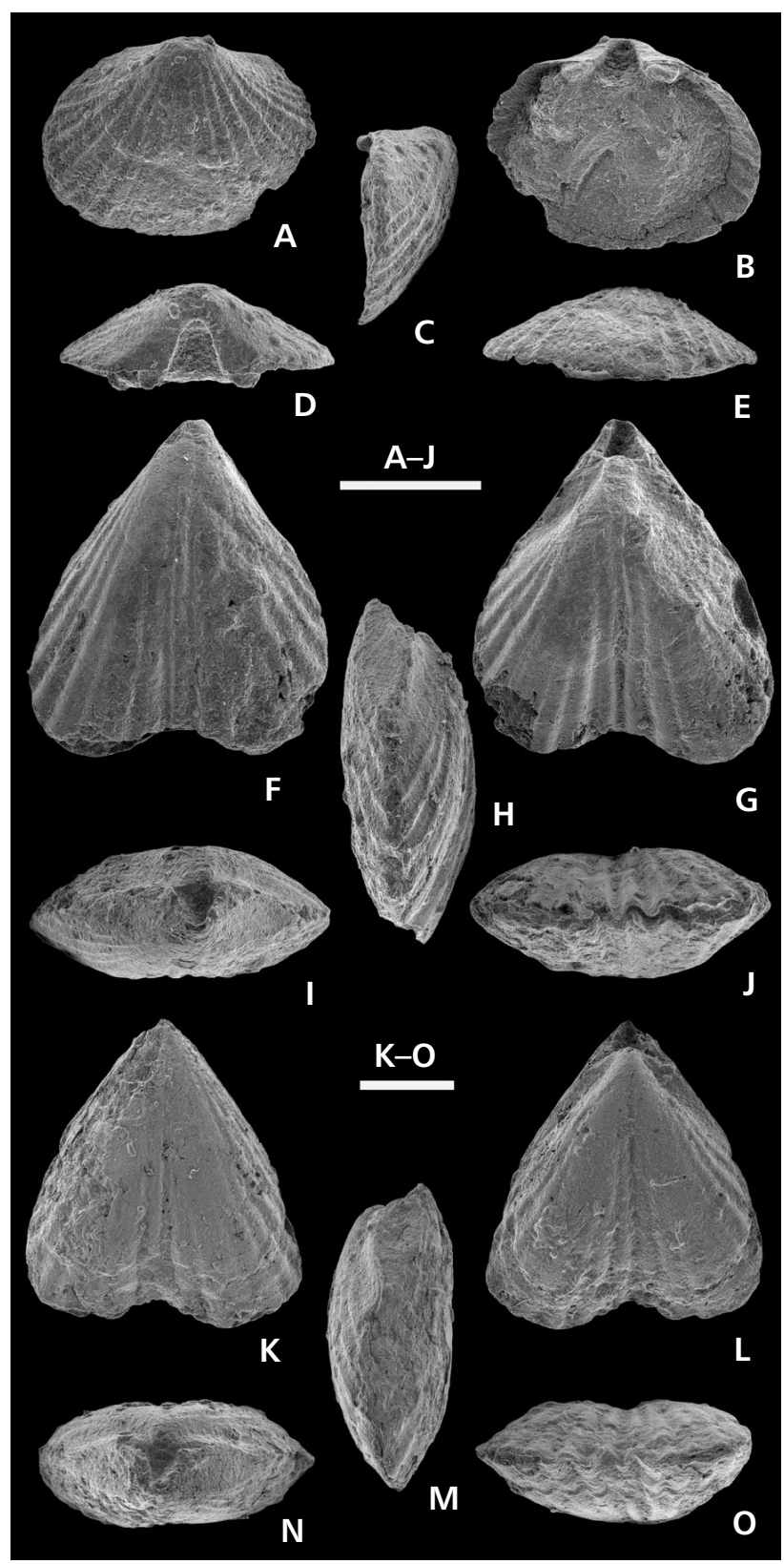

Figure 8. A-E - Schizophoria sp. indet. Almost complete ventral valve (TCD.60931) in external, internal, lateral, posterior and anterior views. - F-O - Tretorhynchia cf. trilatera (de Koninck, 1843). - F-J - articulated specimen (TCD.60933) in ventral, dorsal, lateral, posterior and anterior views. $-\mathrm{K}-\mathrm{O}$ - articulated specimen (TCD. 60934) in ventral, dorsal, lateral, posterior and anterior views. All the specimens are from the Meenymore Formation, Gleniff. Scale bars: $1 \mathrm{~mm}$.

transfer the subfamily Tretorhynchinae to the Leiorhynchidae (Camarotoechioidea) on the basis of the internal structures, but here we follow Savage's (2002) classification as the development of endopunctae in rhynchonellid shells is unusual and, thus, is considered as a significant parameter for classification. 


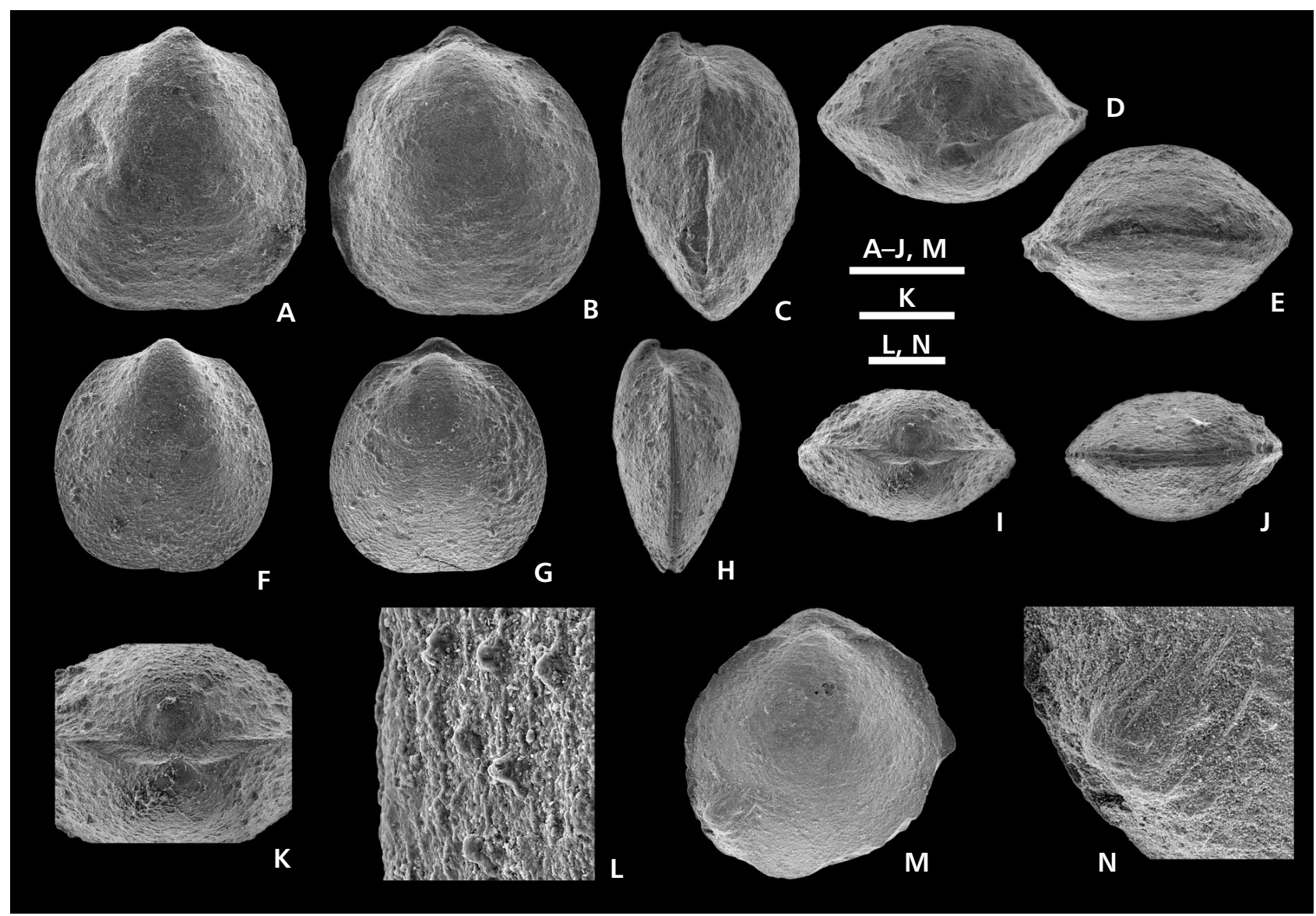

Figure 9. Nucleospira aff. carlukensis (Davidson, 1859) from the Meenymore Formation, Gleniff. • A-E - articulated specimen (TCD.60936) in ventral, dorsal, lateral, posterior and anterior views. $\bullet$ F-L - articulated specimen (TCD.60937) in ventral, dorsal, lateral, posterior and anterior views and details of the ventral area (note the circular drill hole on the right of the dorsal umbo) and the microspinous external ornamentation. $\bullet \mathrm{M}, \mathrm{N}-$ incomplete articulated specimen (TCD.60938) in dorsal view with microspinous external ornamentation preserved and detail of it. Scale bars: $1 \mathrm{~mm}$, except $\mathrm{K}(500 \mu \mathrm{m}), \mathrm{L}(50 \mu \mathrm{m})$, and $\mathrm{N}(200 \mu \mathrm{m})$.

Order Athyridida Boucot et al., 1964

Suborder Athyrididina Boucot et al., 1964

Superfamily Nucleospiroidea Davidson, 1881

Family Nucleospiridae Davidson, 1881

\section{Genus Nucleospira Hall, 1858 in Davidson (1858)}

Type species. - Spirifer ventricosus Hall, 1857; from the Lower Helderberg Group, Lochkovian, New York, USA.

\section{Nucleospira aff. carlukensis (Davidson, 1859)}

Figures 9A-N, 11A-D

aff. 1859 Spirifera carlukensis; Davidson, p. 59, pl. 13, figs $14,14 \mathrm{a}, \mathrm{b}$.

Material. - Eleven specimens with conjoined valves and one incomplete dorsal valve (TCD.60936-60940).

Description. - Shell small-sized (at least $2.4 \mathrm{~mm}$ in width, but probably larger as demonstrated by a fragmentary dorsal valve; Fig. 11A-D), roughly elliptical in outline, dorsibiconvex (Tv/Td: $0.8-0.87[\mathrm{n}=2])$ and slightly longer than wide (W/L: 0.93-0.94 [n= 2]); hinge line straight, narrower than maximum width $(\mathrm{Wi} / \mathrm{W}$ : $0.51-0.53[\mathrm{n}=2])$; anterior margin straight or slightly emarginate in ventral view; anterior commissure rectimarginate to weakly undulose. Ventral valve with prominent umbo; beak very slightly curved; interarea triangular, low, apsacline, concave; delthyrium wide, open; very shallow depression developed in anterior part of some shells; no dorsal interarea. Dorsal valve with prominent umbo and greatest convexity at or posteriorly to mid-valve; no interarea; no fold.

Shell smooth but with growth lines visible close to the lateral and anterior margins; numerous delicate spines, generally broken (Fig. 9L-N).

Ventral interior unknown. Dorsal valve interior with cardinal flange strongly posteriorly recurved (crura broken) (Fig. 11A-D); dental sockets deep. 
Remarks. - The presence of spines covering the shell surface, the apsacline ventral interarea and the markedly posteriorly recurved cardinal flange are characteristic of the genus Nucleospira. The outline of these small shells is similar to that of the lectotype of $N$. carlukensis (Davidson, 1859) from the late Viséan of Lanarkshire, which was chosen but only partially illustrated by Brunton (1984, fig. 77), but specimens of similar size have not been found at Gleniff and display a clearly dorsibiconvex profile. Our specimens are smaller but externally close to those from the Upper Glencar Formation assigned to Nucleospira carlukensis by Brunton (1984; see also Brunton et al. 1996), despite the fact that they do not display thickened growth lines (see Brunton 1984, figs 79a, 80b). Furthermore, our material shares a similar outline with that of N. rowleyi Weller, 1914 from the Louisiana Limestone of Missouri, but displays a more dorsibiconvex profile. On the basis of their external shape, we presently underline the similarities between the Gleniff species and that of Davidson (1859), but more data (e.g. ventral internal features) are necessary to reliably discriminate these tiny brachiopod species.

Superfamily Retzioidea Waagen, 1883

Family Neoretziidae Dagys, 1972

Subfamily Hustediinae Grunt, 1986

\section{Genus Hustedia Hall \& Clarke, 1893}

Types species. - Terebratula mormoni Marcou, 1858; from the Moscovian (Desmoinesian) "Mountain Limestone" near Salt Lake City, Utah, USA.

\section{Hustedia radialis (Phillips, 1836)}

Figure 10A-T

1836 Terebratula radialis Phillips; p. 223, pl. 12, figs $40,41$.

1974 Hustedia cf. radialis (Phillips). - Brunton \& Champion, p. 825, pl. 109, figs 10-18.

1984 Hustedia radialis (Phillips). - Brunton, p. 44, figs 30-38 (see this author for a more complete synonymy).

1991 Hustedia radialis (Phillips). - Brunton \& Tilsley, pp. 290, 292.

Material. - Thirty-nine articulated specimens, one ventral and one dorsal valve (TCD.60941-60945).
Description. - Shell small-sized (ca $5 \mathrm{~mm}$ in width), slightly longer than wide (W/L: 0.82-0.93 [n=3]), widest at about midlength, ventribiconvex (Tv/Td: 1.09-1.65 $[n=4])$, suboval in outline; hinge line clearly shorter than greatest shell width (Wi/W: 0.33-0.4 [n = 3]); anterior margin rounded in ventral view; commissure rectimarginate or very slightly sulcate. Ventral valve with prominent umbo and greatest convexity posteriorly to midlength; foramen large, circular, permesothyrid; interarea small, flat to weakly concave, apsacline; symphythium flat; no sulcus and no fold. Dorsal valve with or without shallow sulcus arising in its posterior part and with greatest convexity slightly posterior to valve midlength.

Ornamentation of $c a$ 16-18 simple, rounded ribs on the dorsal valve, separated by intercostal grooves of similar section; one specimen displaying one growth line exceptionally thickened on both valves (Fig. 10A-C).

Internal morphology not observed.

Remarks. - Although their internal morphology is unknown, the specimens from Gleniff are essentially identical with those assigned to Hustedia radialis by Brunton \& Champion (1974) and Brunton (1984). A single specimen exceptionally displays one thickened growth line on both valves (Fig. 10A-C). Growth lines have not been reported before in $H$. radialis, but this may be simply the result of an accident during growth, such storm inflicted damage to the mantle arresting growth abruptly (L. Angiolini, pers. comm. 2014). Brunton (1984) doubtfully placed Hustedia multiplicata (de Koninck, 1887) (misspelled multicostata in the legend of de Koninck's plate 22), from the Tournaisian of Tournai (Tournai Formation; see also Demanet 1958), in synonymy with $H$. radialis. The specimens identified as Hustedia multiplicata and illustrated by de Koninck (1887, pl. 22, fig. 20 [IRScNB a5512] and figs 21-24 [IRScNB a5513]) are here illustrated photographically for the first time. The specimen IRScNB a5513 is here chosen as lectotype (Fig. 10U-Y) of de Koninck's species, which differs at first sight from Hustedia radialis by its subcircular outline but displays the same number of dorsal ribs as the lectotype of Phillips' species (see Brunton 1984, fig. 32). The second specimen (IRScNB a5512; Fig. 10Z-CC) illustrated by de Koninck (1887) differs from the lectotype of Hustedia multiplicata by its outline, which is similar to that of $H$. radialis but is here provisionally identified as $H$. sp. indet. More specimens from Tournai are required to discuss similarities and differences between both species further (including data on size and internal features).

Figure 10. A-T - Hustedia radialis (Phillips, 1836) from the Meenymore Formation, Gleniff. • A-E - juvenile articulated specimen (TCD.60941) in ventral, dorsal, lateral, posterior and anterior views (note the exceptional development of a growth line in both valves). $\bullet \mathrm{F}-\mathrm{J}-\mathrm{juvenile}$ articulated speci- 


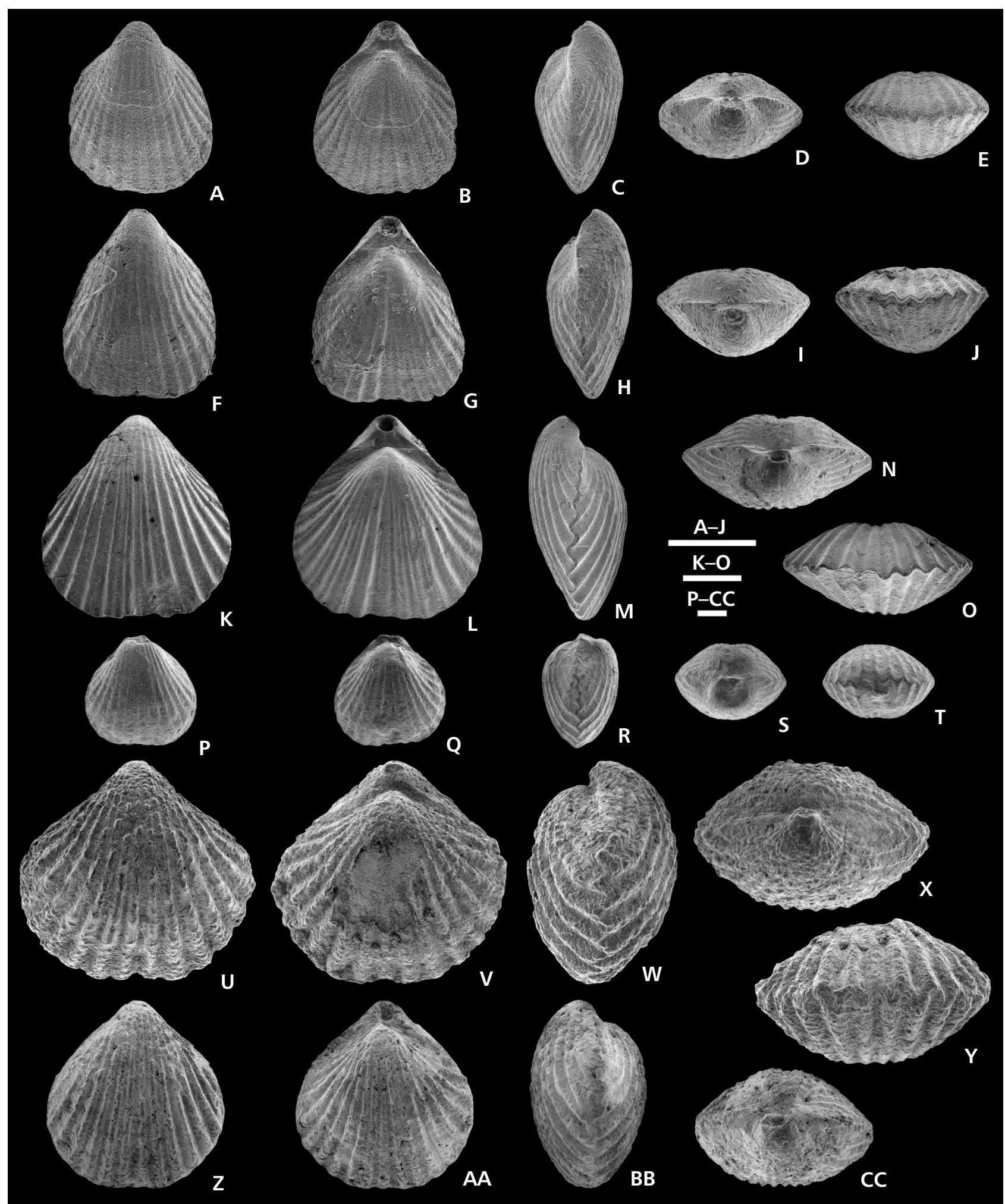

men (TCD.60942) in ventral, dorsal, lateral, posterior and anterior views. $\bullet \mathrm{K}-\mathrm{O}-$ articulated specimen (TCD.60943) in ventral, dorsal, lateral, posterior and anterior views. $\bullet$ P-T - articulated specimen (TCD.60944) in ventral, dorsal, lateral, posterior and anterior views. $\bullet$ U-Y - Hustedia multiplicata (de Koninck, 1887), from the Tournaisian Tournai Formation, Tournai (southern Belgium). Articulated specimen (lectotype, IRScNB a5513, illustrated by de Koninck 1887, pl. 22, figs 21-24) in ventral, dorsal, lateral, posterior and anterior views. • Z-CC - Hustedia sp. indet. from the Tournaisian Tournai Formation, Tournai (southern Belgium). Articulated specimen (IRScNB a 5512, illustrated by de Koninck 1887, pl. 22, fig. 20) in ventral, dorsal, lateral, posterior and anterior views. Scale bars: $1 \mathrm{~mm}$. 


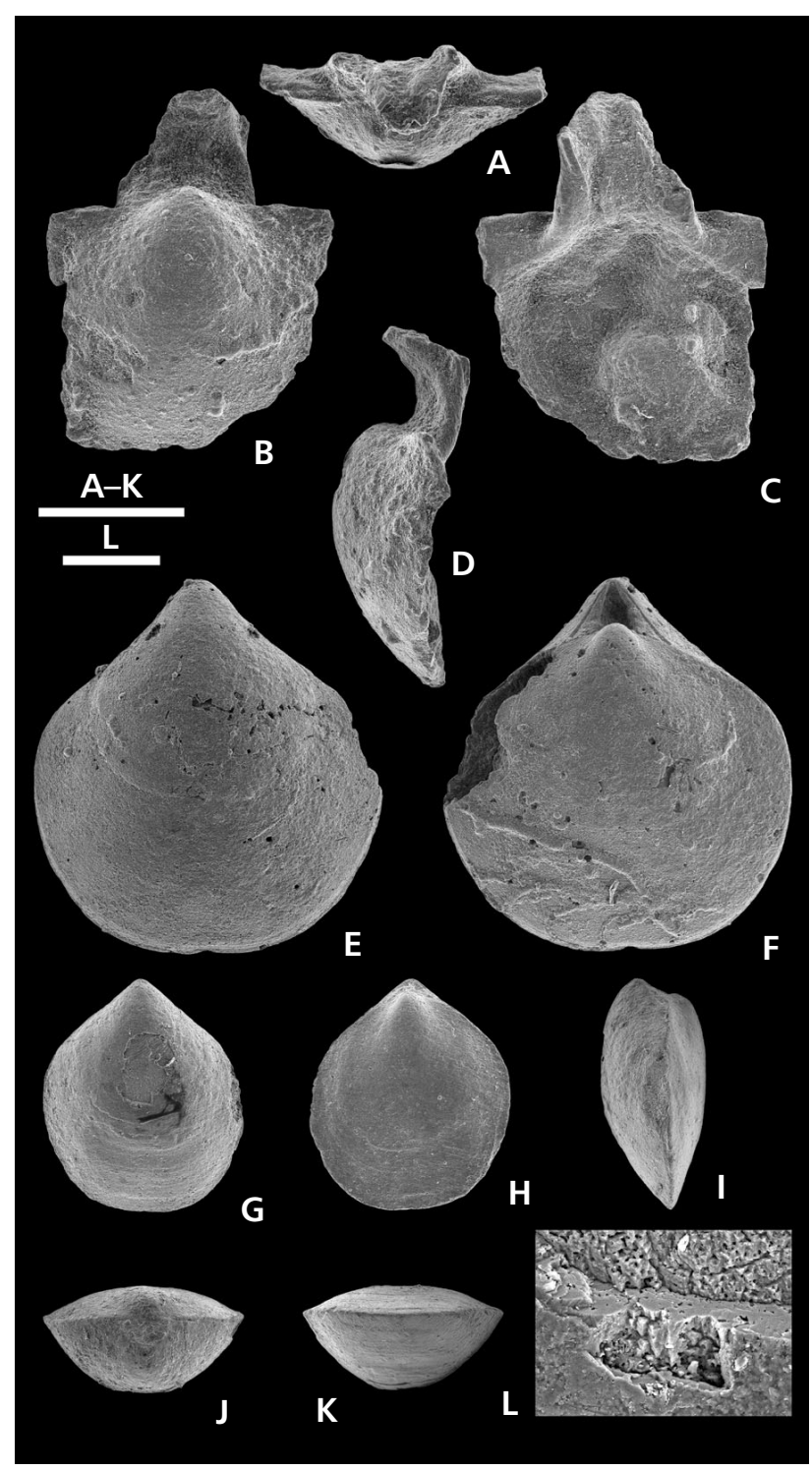

Figure 11. A-D - Nucleospira aff. carlukensis (Davidson, 1859). Fragmentary dorsal valve (TCD.60939) in posterior, external, internal and lateral views. $\bullet \mathrm{E}-\mathrm{L}$ - undetermined athyridide. $\bullet \mathrm{E}, \mathrm{F}-$ almost complete articulated specimen (TCD.60946) in ventral and dorsal views. - G-L - juvenile articulated specimen (TCD.60947) in ventral, dorsal, lateral, posterior and anterior and detail of the impunctate shell. All the specimens are from the Meenymore Formation, Gleniff. Scale bars: $1 \mathrm{~mm}$ (A-K) and $50 \mu \mathrm{m}(\mathrm{L})$.

Athyridide gen. et sp. indet. Figure $11 \mathrm{E}-\mathrm{L}$

Material. - Four articulated specimens and one ventral valve (TCD.60946-60948).

Remarks. - These small (ca up to $2.3 \mathrm{~mm}$ in width), smooth (with scarce obscure growth lines), ventribiconvex and rectimarginate shells are considered as representatives of the order Athyridida as they possess an astrophic and im- punctate shell. The largest specimen displays deltidial plates that partially covered the delthyrium (no foramen is developed). However, they cannot be assigned to a known genus because the internal features are unknown. Our material shares external similarities (e.g. outline, palintrope), except the presence of deltidial plates, with some unidentified athyridides illustrated by Sun \& Baliński (2011, figs $35 \mathrm{~A}-\mathrm{N}$ ) from the Tournaisian Muhua Formation of South China.

Order Spiriferida Waagen, 1883

Suborder Spiriferidina Waagen, 1883

Superfamily Ambocoelioidea George, 1931

Family Ambocoeliidae George, 1931

Subfamily Ambocoeliinae George, 1931

\section{Genus Crurithyris George, 1931}

Type species. - Spirifer urei Fleming, 1828; from the Viséan of Strathaven, Lanarkshire, Scotland.

\section{Crurithyris sp. 1}

Figure 12

Material. - Nine articulated specimens and eleven ventral valves (TCD.60949-60952).

Description. - Shell small-sized (up to $c a 2.5 \mathrm{~mm}$ in width), markedly ventribiconvex (Tv/Td: 2.35-3.85 $[\mathrm{n}=2]$ ), slightly longer than wide to wider than long (W/L: $0.97-1.12[\mathrm{n}=3]$ ), rounded in outline, widest at about midlength; hinge line markedly narrower than greatest shell width (Wi/W: 0.51-0.59 [ $\mathrm{n}=2]$ ); anterior commissure rectimarginate; anterior margin straight or very slightly emarginate in ventral view. Ventral valve with prominent umbo and greatest convexity posteriorly to midlength; faint median depression present in some specimens; beak slightly curved; interarea cata-apsacline, moderately high, concave; in juveniles, top of delthyrium with semi-circular opening bordered by thickened shell layer resembling the extension of narrow deltidial plates (see remarks below). Dorsal valve with greatest convexity posteriorly to midvalve, inflated umbonally; interarea lower than ventral one, anacline, slightly concave.

Shell covered with numerous spine bases of two types (thin and large ones; Fig. 12F).

Ventral interior with small teeth (Fig. 12J) (other features not visible). Dorsal interior unknown.

Remarks. - These specimens are assigned to Crurithyris on the basis of the external features (e.g. shell strongly ventribiconvex, ornamentation of two types of spines). The poor state of preservation of the largest specimens does not allow 
confirmation that the semicircular opening developed at the top of the delthyrium (Fig. 12B, J) was reduced during the growth of the organism, but it is highly probable. An identical structure has been illustrated by Sun \& Baliński (2011, fig. 23B1) in Crurithyris cf. nastus Brunton \& Champion, 1974 from the Tournaisian of South China. From the viewpoint of specific identification, the lack of knowledge of the internal features, which are especially important in the case of small-sized smooth brachiopods devoid of external significant features, remains problematic. Among the species known from the Viséan of the Britain and Ireland (George 1931; Brunton \& Campion 1974; Brunton 1976, 1984), the specimens from Gleniff are externally closer to $C$. nastus than to $C$. urei (Fleming, 1828) on the basis of the dorsal valve profile, which is umbonally inflated. However, for the reasons discussed above, it is better to leave these specimens provisionally in open nomenclature. Moreover, a thorough comparative study of Mississippian ambocoeliides from Western Europe, notably those described by George (1931) and those illustrated but not described by de Koninck (1887; see Mottequin \& Legrand-Blain 2010), is urgently needed to assess better the diversity of this family during this interval, and especially the nature of the spines, but is beyond the scope of this paper.

Crurithyris? sp. indet.

Figure 13

Material. - Twelve articulated specimens and one dorsal valve (TCD.60953-60958).

Description. - Shell small-sized (ca $3 \mathrm{~mm}$ in width), ventribiconvex (Tv/Td: 1.36-1.66 [ $\mathrm{n}=5]$ ), slightly longer than wide to slightly wider than long (W/L: 0.96-1.07 [n=3]), rounded in outline, widest at about midlength; hinge line narrower than greatest shell width (Wi/W: 0.42-0.47 $[\mathrm{n}=3])$; anterior commissure rectimarginate; anterior margin emarginate in ventral view. Ventral valve with prominent umbo and greatest convexity posteriorly to midlength; sulcus generally developed, originating anteriorly to midlength; beak not curved; interarea apsacline, moderately high and concave; delthyrium triangular with no deltidial plates. Dorsal valve regularly convex with greatest convexity posteriorly to mid-valve length but not particularly inflated umbonally; sulcus shallow, arising in valve posterior part; interarea linear, anacline, slightly concave.

Shell smooth except some growth lines (no spine bases observed).

Internal morphology unknown.

Remarks. - On the basis of the external morphology, these specimens are doubtfully assigned to Crurithyris as they do

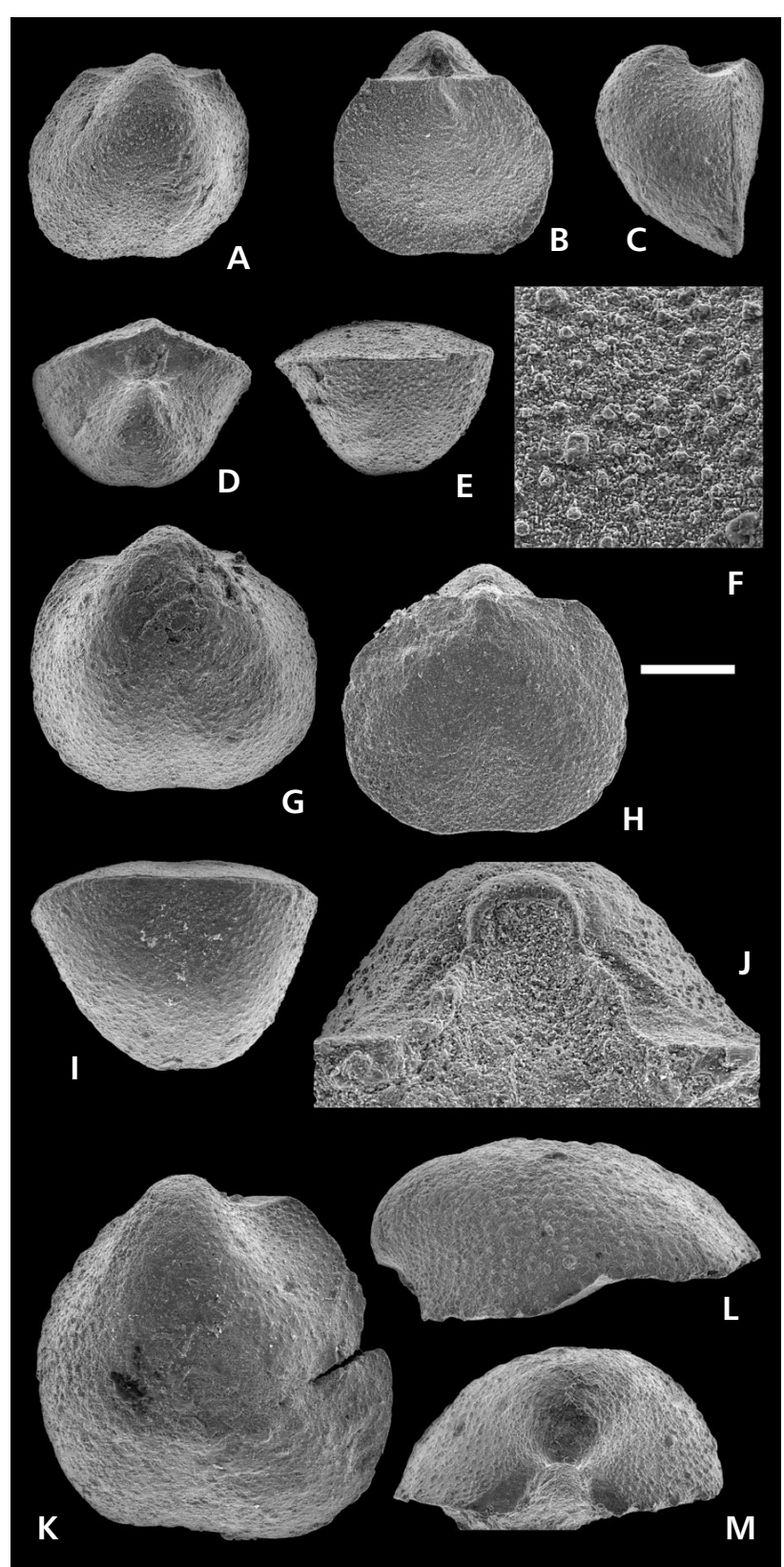

Figure 12. Crurithyris sp. 1 from the Meenymore Formation. $・ A-F-$ articulated specimen (TCD.60949) in ventral, dorsal, lateral, posterior and anterior view and detail of the microspinous external ornamentation (small and large spine bases are visible). • G-I - articulated specimen (TCD.60950) in ventral, dorsal, and anterior views. $\bullet \mathrm{J}-\mathrm{M}-$ detail of the interarea of a ventral valve (TCD.60951) and the same in ventral, lateral and posterior views. Scale bar: $500 \mu \mathrm{m}$, except $\mathrm{F}(50 \mu \mathrm{m})$ and $\mathrm{J}(75 \mu \mathrm{m})$.

not show spines - however the absence of the latter may be a preservation bias although this seems to be unlikely as the other brachiopod species display minute details of their microornament -, and the absence of deltidial plates. Besides these features, they differ markedly from Crurithyris sp. 1 notably in their less inflated shell and their more developed sulci. On the basis of the external features (e.g. short 
hinge line, rounded lateral extremities, biconvex shell), an assignment to the Martinioidea may be envisaged, but the lack of data related to their internal morphology, which is crucial for discrimination (e.g. knoblike cardinal process in Ambocoelioidea vs. ctenophoridium in Martinioidea), precludes a more detailed discussion.

Order Spiriferinida Ivanova, 1972

Suborder Spiriferinidina Ivanova, 1972

Superfamily Pennospiriferinoidea Dagys, 1972

Family Punctospiriferidae Waterhouse, 1975

\section{Genus Punctospirifer North, 1920}

Type species. - Punctospirifer scabricosta North, 1920; from the top of the Ashfell Sandstone Formation (Viséan, late Arundian), Westmoreland, England.

\section{Punctospirifer? sp. indet.}

Figure 14

Material. - Five articulated specimens, three ventral and two dorsal valves (TCD.60959-60964).

Description. - Shell small-sized ( $c$ a $4 \mathrm{~mm}$ in width for the largest, but flattened specimen), wider than long (W/L: $1.18[\mathrm{n}=1])$, ventribiconvex (Tv/Td: $1.82[\mathrm{n}=1])$, rounded subpentagonal in outline with rounded cardinal angles, widest at about midlength; hinge line narrower than greatest shell width (Wi/W: $0.67[\mathrm{n}=1])$; anterior commissure uniplicate; anterior margin slightly emarginate in ventral view. Ventral valve with flanks steeply sloping towards lateral margins; umbo prominent; beak curved; interarea moderately high (Hi/Wi: $0.22[\mathrm{n}=1])$, triangular, apsacline, concave; delthyrium open; sulcus well delimited by strong sulcal ribs, wide (Ws/W: $0.47[\mathrm{n}=1]$ ), flat-bottomed at front. Dorsal valve with low but well defined, flat-topped fold; interarea linear, flat, orthocline.

Fold and sulcus smooth; on ventral valve, about 4 lateral ribs arising anteriorly to the umbo (except the sulcal bounding ribs) but obscure on posterolateral parts of flanks; microornament of imbricate and closely spaced growth lines and discontinuous capillae becoming wider with the imbrications anteriorly as tiny U-shaped crenulations of lamellae (Fig. 14P, Q).

Ventral interior unknown. Dorsal valve interior (Fig. 14N, O) with deep dental sockets; inner socket ridges diverging at an angle of $49^{\circ}(n=1)$; cardinal process badly preserved, sessile (?); crural plates long (?).

Remarks. - On the basis of the available data, and despite the lack of knowledge of the ventral internal morphology, the nature of the shell (impunctate or punctate) and a mar- kedly rounded outline, our material is tentatively assigned to Punctospirifer. This is on the basis of the microornament (see discussion in Campbell 1959 and Carter 1999). Tylothyris North, 1920, which is also characterized by numerous imbricate growth lamellae, is devoid of capillae, at least in the type species (see Brunton 1984 and Mottequin 2010). By their overall shape, their small size and their obsolescent lateral ribs, the Gleniff specimens display some similarities of the external shell with the type species of Texathyris Carter, 1972, i.e. T. elegantula Carter, 1972, but they can be readily distinguished from this species notably by the presence of capillae and the fold which is not bounded by two deep grooves. Brunton (1987) reported that Punctospirifer scabricosta North, 1920 occurs abundantly within the Dartry Limestone Formation in Co. Fermanagh but did not illustrate the species.

Order Terebratulida Waagen, 1883

Suborder Terebratulidina Waagen, 1883

Superfamily Cryptonelloidea Thomson, 1926

Family Cryptonellidae Thomson, 1926

Subfamily Cryptonellinae Thomson, 1926

\section{Genus Cryptonella Hall, 1861}

Type species. - Terebratula rectirostra Hall, 1860; from the Mid Devonian of western New York, USA.

\section{Cryptonella? sp. indet.}

Figure 15

Material. - Seven articulated specimens (TCD.60965 to 60967).

Description. - Shell small-sized (4.3 $\mathrm{mm}$ for the largest specimen), longer than wide, aequibiconvex to slightly ventribiconvex, elongate in outline, widest at about the two thirds of the shell; anterior commissure rectimarginate; anterior margin relatively rounded in ventral view. Ventral umbo prominent, beak straight, pierced by permesothyrid foramen; delthyrium concealed with deltidial plates. Dorsal valve regularly convex both in posterior and lateral profile views and with greatest convexity at mid-valve.

Shell covered with growth lines.

Internal morphology unknown.

Remarks. - The lack of knowledge about the internal features precludes a definite generic assignment. However, some external features such as the ventral beak being not incurved, which allows the exposition of the deltidial plates, suggest a possible assignment to Cryptonella Hall, 1861, whose representatives are particularly rare within the Mississippian (Brunton 1984) - C. minranensis Brunton, 


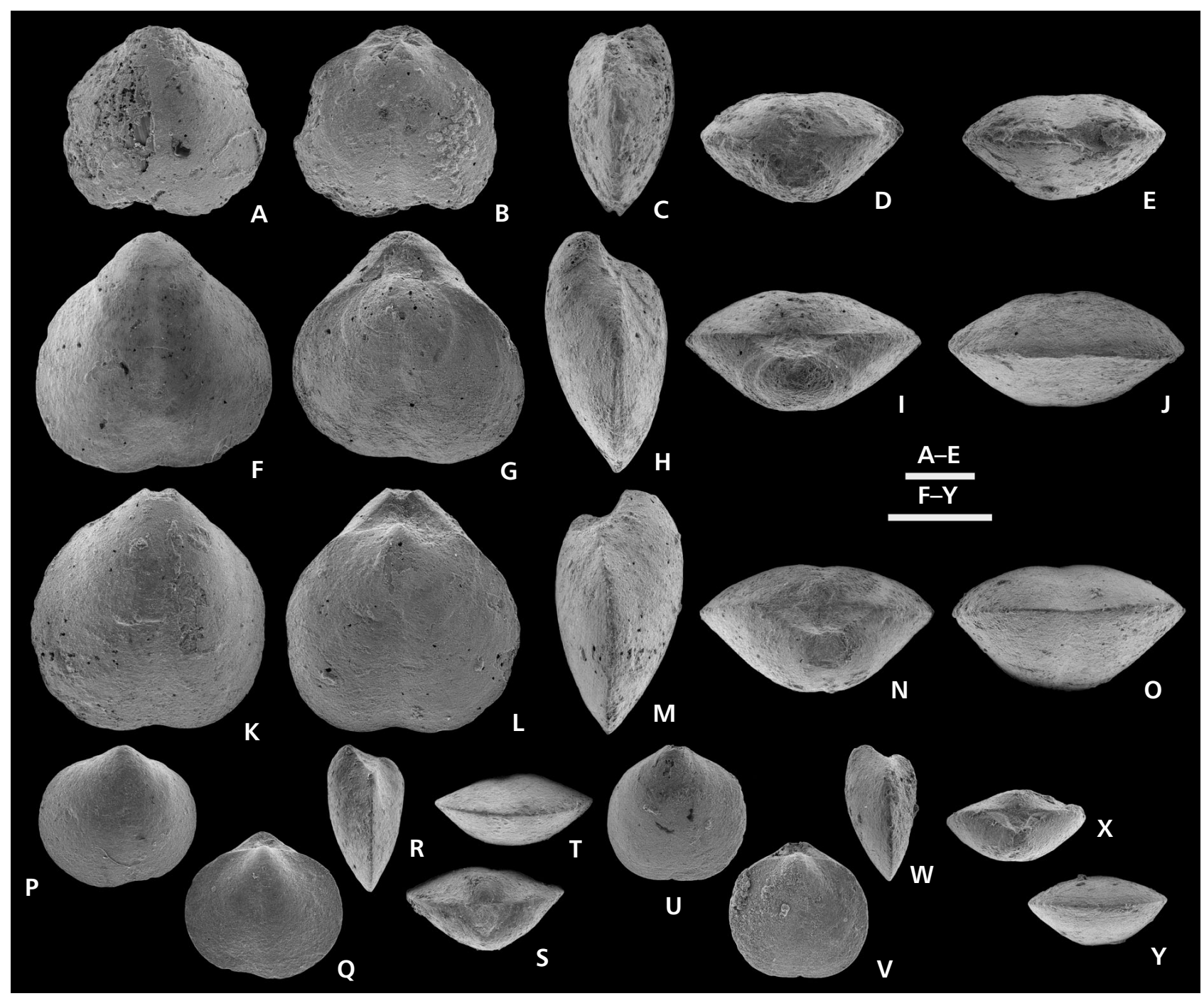

Figure 13. Crurithyris? sp. indet. from the Meenymore Formation, Gleniff. • A-E - incomplete articulated specimen (TCD.60953) in ventral, dorsal, lateral, posterior and anterior views. • F-J -articulated specimen (TCD.60954) in ventral, dorsal, lateral, posterior and anterior views. $\bullet \mathrm{K}-\mathrm{O}$ - articulated specimen (TCD.60955) in ventral, dorsal, lateral, posterior and anterior views. • P-T - juvenile articulated specimen (TCD.60956) in ventral, dorsal, lateral, posterior and anterior views. $\bullet \mathrm{U}-\mathrm{Y}$ - juvenile articulated specimen (TCD.60957) in ventral, dorsal, lateral, posterior and anterior views. Scale bars: $1 \mathrm{~mm}$.

1984 from the Viséan of Co. Fermanagh (several horizons of the Glencar Formation; Brunton 1987) - and Pennsylvanian (Pérez-Huerta 2004) strata.

\section{Palaeoecology}

Brandon (1977) showed that much of the Meenymore Formation was deposited in restricted environments associated with tidal flats, with several horizons of stromatolites, dolomicrites and evaporites. The relatively rare horizons with fossils contain faunas that are different from those of the open marine Glencar and Dartry formations, which include colonial rugose corals and large brachiopods and crinoids. The fauna from the Meenymore Formation of the
Gleniff outlier is characterised by small-sized fossils, including the brachiopods described above, molluscs, notably ammonoids, nautiloids, gastropods and rostroconchs, a varied fauna of echinoderms, discussed by Sevastopulo (2002), and ostracodes and rare trilobites. Corals and bryozoans are extremely poorly represented in terms of both numbers of individuals and of taxa. Many of the fossils are encrusted with a micrite crust, which is probably microbial in origin.

The brachiopod fauna is relatively diverse and well preserved. Nevertheless, the use of diversity indices (e.g. Margalef and Shannon-Wiener) is not very useful because, as explained above and due to the poor exposure of the rocks assigned to the Meenymore Formation at Gleniff, the sampling method may have resulted in the amalgamation 
of several subfacies. At least 14 species have been found and most of the specimens correspond to tiny adults (micromorphs), although juveniles of larger species are present within the assemblage; this degree of diversity is similar to that reported from the Viséan (Warnantian) of Badajoz in SW Spain by Martínez Chacón (1997) but the Irish and Spanish assemblages are markedly different in their generic composition. At Gleniff, spire-bearers (Athyridida, Spiriferida, and Spiriferinida) represent $40 \%$ of the whole assemblage with six species but, in terms of numbers of specimens, the orthotetides, represented only by Drahanorhynchus gleniffensis sp. nov., are the most abundant. Due to the reasons discussed above, it is not possible to determine if this species is an opportunist with respect to the spire-bearing brachiopods. As information about the internal features are lacking for most of the taxa, the results of the systematic study should be considered as provisional. Nonetheless, the Gleniff assemblage is considerably less diverse than that from the slightly older open marine faunas from the Asbian Upper Glencar Limestone and the Dartry Limestone in nearby localities of County Fermanagh where 56 species were recognized (Brunton 1966a, 1968, 1984, 1987; Brunton \& Mason 1979; Brunton \& Mundy 1986). Brunton (1987) suggested that this exceptional diversity most probably resulted from the association with carbonate mudbank environments or their close proximity, following Boucot's (1975) opinion that attributed higher diversity assemblages to reefal environments than to level-bottomed ones. It is notable that the smooth rhynchonellide Lambdarina has not been found at Gleniff nor in the faunas described by Brunton (1966a) although it is a common element of micromorph faunas from the Tournaisian and Viséan of Western Europe (Brunton \& Champion 1974, Bassett \& Bryant 1993, Morris 1994, Martínez Chacón 1997) and elsewhere in the world (see references in Baliński \& Sun 2008).

As mentioned by Brunton (1987), the degree of articulation, the state of preservation of the most delicate ornamental structures and the infestation by organisms after death are of considerable importance in establishing the assemblage type. The percentage of articulated specimens of spiriferides, athyridides, rhynchonellides and terebratulides, which are all characterized by strong articulatory processes, is high. This is not the case for the orthotetides and orthides, which are all disarticulated, and only a small proportion of the specimens of chonetidines remain articulated. The preservation of the minute spiny projections present in the orthotetide D. gleniffensis sp. nov. (Fig. 6V, W) or the spine bases in Crurithyris sp. 1 (Fig. 12F) and Nucleospira sp. (Fig. 9L-N) is exceptional to common. Growth microlines are very well preserved in numerous specimens of the former as well as in the spiriferides. Spines developed along the hinge line in Globosochonetes are also well preserved. It thus seems likely that the Gleniff assemblage represent an in situ accumulation (life assemblage), although time-averaged.

The small body of the brachiopods and their thin shell may allow them to raft on the muddy substrate, with only limited hard counterparts provided by skeletobionts (see above), but they were probably very sensitive to sediment disturbances due to their sessile mode of life (e.g. Tomašových 2006). Brachiopods with an open delthyrium or foramen are normally interpreted as having lived attached to various kinds of substrate (e.g. lime mud, shells, algae) by their pedicle; the orthotedides clearly display a small cementation cicatrix (Fig. 6G-I) at the top of the ventral umbo with koskinoid perforations (Jux \& Strauch 1966). There is no consensus about the origin of these minute perforations. They may be drilled mechanically by boring organisms (Thomas 1958, Williams \& Brunton 1993) or be related to development of an attachment organ (e.g. Grant 1976, 1980; Martínez Chacón \& García-Alcalde 1978). Some productidines are found attached to crinoid ossicles by thin clasping spines (see also Brunton 1965, 1966a and Sun \& Baliński 2008 for discussion about the mode of attachment of productidines).

Post-mortem (?) encrustations by enigmatic organisms (Figs 6X, 7A) was noted in D. gleniffensis sp. nov. and circular drill holes, perpendicular to the shell surface were observed in the athyridides Hustedia (Fig. 10K, L) and Nucleospira (Fig. 9G-K) but these have not been studied quantitatively because the number of specimens is too limited (see e.g. Brunton 1966b, Bassett \& Bryant 1993, Morris 1994, Martínez Chacón 1997, Baumiller et al. 1999, Deline et al. 2003, Mottequin \& Sevastopulo 2009, Mottequin 2010, Sun \& Baliński 2011 for drill holes in Mississippian brachiopods).

The reasons for the large percentage of micromorph taxa of brachiopods in the Gleniff fauna, which is mirrored by the echinoderms (Sevastopulo 2002, 2008), are difficult to elucidate but their small size is probably the result of the combination of several biotic (e.g. food supply) and physicochemical (e.g. water oxygenation) factors. It is unlikely to be a consequence of abnormal salinity, because both echinoderms and brachiopods are largely stenohaline. What is notable about the Gleniff fauna is that most of the sessile benthos was epifaunal suspension feeders confined to the lowest epifaunal tier of the spectrum of tiering discussed by Ausich \& Bottjer (1982). Fenestrate bryozoans, many of which would have occupied a slightly higher level in the hierarchy of tiering, are conspicuously rare. According to Pérez-Huerta \& Sheldon (2006), nutrient availability played an important role in controlling the size of the spire-bearering brachiopods (athyridides, spiriferides, and spiriferinides), which may have only reached a large size when food supply was abundant, and would tend to be smaller otherwise, as for instance in deeper water settings. Thus, the size of the spire-bearing brachiopods would have 


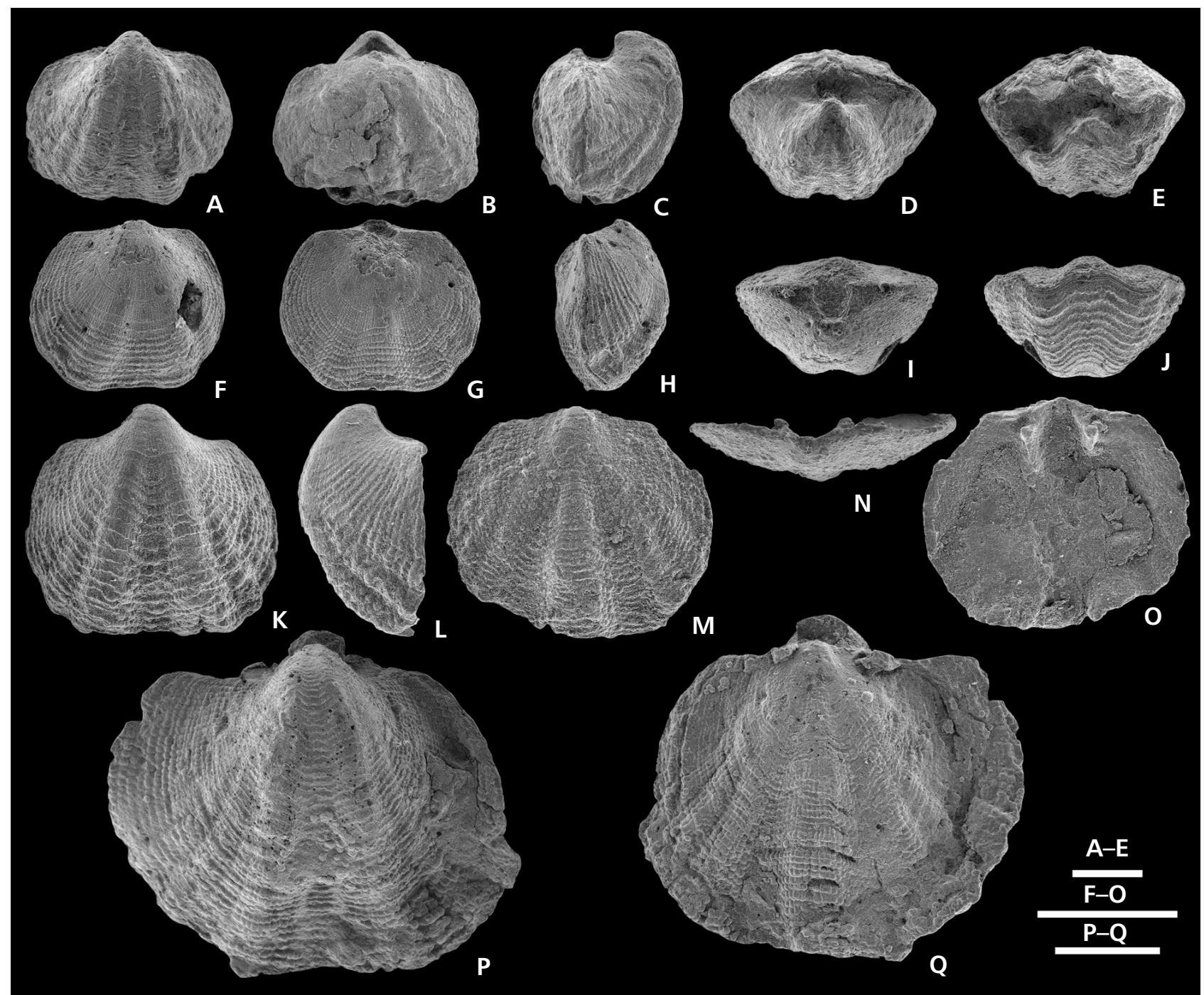

Figure 14. Punctospirifer? sp. indet. from the Meenymore Formation, Gleniff. • A-E - articulated specimen (TCD.60959) in ventral, dorsal, lateral, posterior and anterior views. - F-J - almost complete articulated specimen (TCD.60960) in ventral, dorsal, lateral, posterior and anterior views. - K, L - ventral valve (TCD.60961) in ventral and lateral views. - M-O - dorsal valve (TCD.60962) in external, posterior and internal views. - P-Q - crushed specimen (TCD.60963) in ventral and dorsal views. Scale bars: $1 \mathrm{~mm}$.

been related to food availability and water depth (PérezHuerta \& Sheldon 2006). In contrast, the productides would be larger and dominant in food-depleted environments according to Pérez-Huerta \& Sheldon (2006). Nevertheless, the size of most of the brachiopods occurring in the Gleniff assemblage is similar and thus food availability is probably not the major limiting factor. Several authors (e.g. Fürsich \& Hurst 1974, Pérez-Huerta \& Sheldon 2006) have pointed out the importance of the lophophore efficiency for explaining the differences observed in brachiopod assemblages (spire-bearers vs. productides) but this remain highly conjectural in the absence of modern representatives of these brachiopods. The lophophore of the spire-bearers is thought to have been an efficient filtering system due to its ability to produce strong inhalant and exhalant currents (Fürsich \& Hurst 1974, Vogel 1975, Pérez-Huerta \& Sheldon 2006) while the productide lophophore would have been able to generate multidirectional currents that may have permitted the capture of food particles from a larger area around the shell than in the athyridides or spiriferides for example (Grant 1972, PérezHuerta \& Sheldon 2006). Despite the fact that spire-bearers constitute a large part of the brachiopod assemblage, it is important to note the abundance of the orthotetide Drahanorhynchus gleniffensis sp. nov. with a cementing habit, which was probably equipped with an unsupported low spirolophe (see Grant 1980 for lophophore reconstruction in Derbya). Alexander (1977) reported small-sized brachiopods associated with small fenestrate bryozoans, corals and gastropods in Mississippian reducing, muddy, 


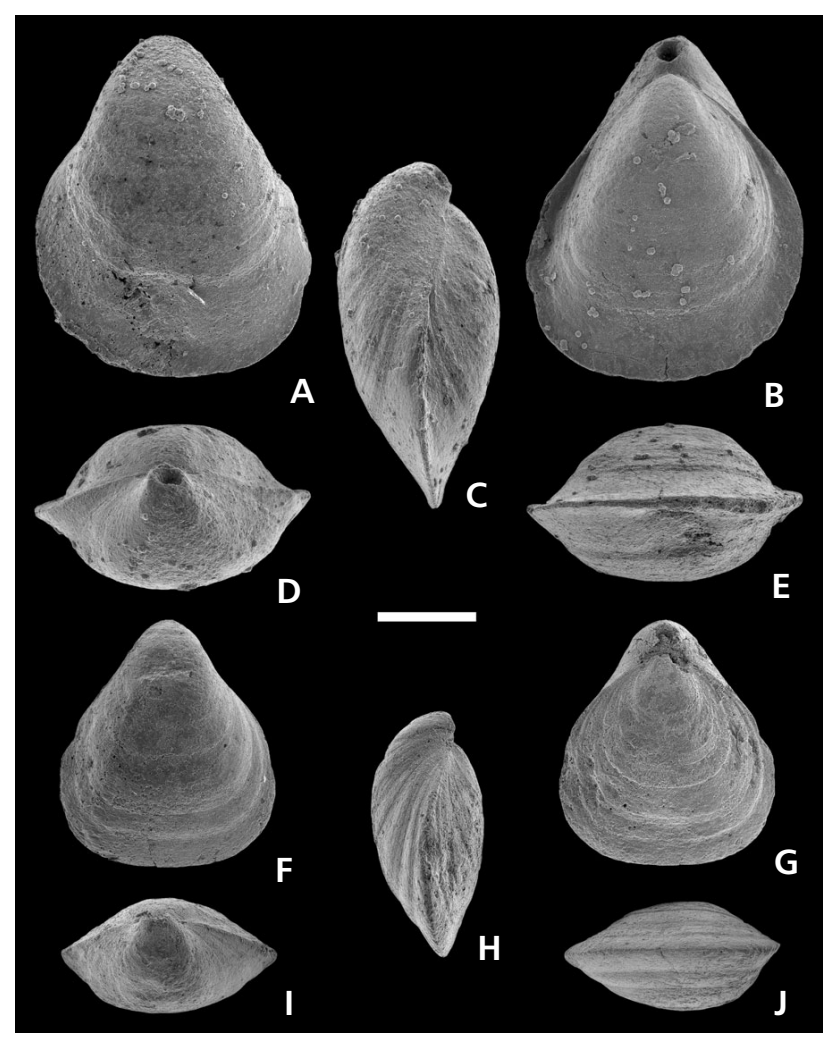

Figure 15. Cryptonella? sp. indet. from the Meenymore Formation, Gleniff. • A-E - articulated specimen (TCD.60965) in ventral, dorsal, lateral, posterior and anterior views. - F-J - articulated specimen (TCD.60966) in ventral, dorsal, lateral, posterior and anterior views. Scale bar: $1 \mathrm{~mm}$.

lagoonal environments of Utah that were characterized by reduced water circulation and agitation. In such a depositional setting similar to that of Gleniff, water oxygenation prevailing on the sea floor was probably not optimal. Furthermore, brachiopod assemblages characterized by small-sized and smooth-shelled species with relatively high surface area to volume ratio were interpreted as reflecting limited trophic resources and/or a poorly oxygenated environment (e.g. Thayer 1986, Levin 2003, Payne et al. 2011, Garbelli et al. 2014).

\section{Conclusions}

The brachiopod assemblage recovered from the late Asbian Meenymore Formation at Gleniff included 14 taxa which mostly belong to the spire-bearers (Athyridida, Spiriferida, and Spiriferinida). Most of the specimens represent micromorphic species but also juveniles of larger ones; no endemic genera were recognized among the material investigated and we can underline the absence of the smooth-shelled rhynchonellide Lambdarina, which is generally a common element in Mississippian small-sized brachiopod faunas. The brachiopod diversity is markedly lower than that known from the Asbian Upper Glencar Formation in which Brunton (1987) reported 56 species, but comparable to the 12 species recognized within non-reef facies of the underlying Dartry Formation (Brunton 1987). These minute brachiopods are associated with other small-sized benthic organisms such as molluscs and echinoderms, but this generalized small size cannot be related to abnormal salinity as brachiopods and echinoderms are generally stenohaline and its causes remain obscure, but is most likely the consequences of the combination of several physicochemical and biotic factors.

\section{Acknowledgments}

The SEM images of the brachiopods were taken at the Royal Belgian Institute of Natural Sciences at Brussels by Julien Cillis. The manuscript benefited from the thorough reviews of Lucia Angiolini and Maria-Luisa Martínez Chacón and from the editorial help of Michal Mergl.

\section{References}

Alexander, R.R. 1977. Growth, morphology and ecology of Paleozoic and Mesozoic opportunistic species of brachiopods from Idaho-Utah. Journal of Paleontology 51, 1133-1149.

Alvarez, F. \& Rong, J.-Y. 2002. Athyridida, 1475-1601. In KAESLER, R.L. (ed.) Treatise on invertebrate paleontology, Part H, Brachiopoda 4 (revised). Geological Society of America \& University of Kansas Press, Boulder \& Lawrence.

AmLER, M.R.W. \& WinkLeR Prins, C.F. 1999. Lower Carboniferous marine bivalves from the Cantabrian Mountains (Spain). Scripta Geologica 120, 1-45.

Archbold, N.W. 1980. Studies on Western Australian Permian brachiopods. I. The family Anopliidae (Chonetidina). Proceedings of the Royal Society of Victoria 91, 181-192.

Ausich, W.I. \& BotTJER, D.J. 1982. Tiering in suspension-feeding communities on soft substrates throughout the Phanerozoic. Science 216, 173-174.

DOI 10.1126/science.216.4542.173

BALIŃSKI, A. \& Sun, Y. 2008. Micromorphic brachiopods from the Lower Carboniferous of South China, and their life habits. Fossils and Strata 54, 105-115.

Bassett, M.G. \& Bryant, C. 1993. The micromorphic rhynchonelloidean brachiopod Lambdarina from the type Dinantian. Journal of Paleontology 67, 518-527.

BAumilleR, T.K., Leighton, L.R. \& Thompson, D.L. 1999. Boreholes in Mississippian spiriferid brachiopods and their implications for Paleozoic drilling. Palaeogeography, Palaeoclimatology, Palaeoecology 147, 283-289. DOI 10.1016/S0031-0182(98)00165-5

Boucot, A.J. 1975. Evolution and extinction rate controls. Developments in Palaeontology and Stratigraphy 1, 1-427.

Boucot, A.J., Johnson, J.G. \& Staton, R.D. 1964. On some 
atrypoid, retzioid, and athyridoid Brachiopoda. Journal of $\mathrm{Pa}$ leontology 38, 805-822.

Brandon, A. 1977. The Meenymore Formation - an extensive intertidal evaporitic formation in the Upper Visean (B2) of north-west Ireland. Report of the Institute of Geological Sciences 77(23), 1-14.

Bronn, H.G. 1862. Die Klassen und Ordnungen der Weichthiere (Malacozoa) wissenschaftlich dargestellt in Wort und Bild, Vol. 3, Part 1. 518 pp. C.F. Winter'sche Verlagshandlung, Leipzig \& Heidelberg.

Brunton, C.H.C. 1965. The pedicle sheath of young productacean brachiopods. Palaeontology 7, 703-704.

Brunton, C.H.C. 1966a. Silicified productoids from the Viséan of County Fermanagh. Bulletin of the British Museum (Natural History), Geology 12, 175-243.

Brunton, C.H.C. 1966b. Predation and shell damage in a Viséan brachiopod fauna. Palaeontology 9, 355-359.

Brunton, C.H.C. 1968. Silicified brachiopods from the Viséan of County Fermanagh (II). Bulletin of the British Museum (Natural History), Geology 16, 1-70.

Brunton, C.H.C. 1971. An endopunctate rhynchonellid brachiopod from the Viséan of Belgium and Britain. Palaeontology $14,95-106$.

BRunton, C.H.C. 1976. Micro-ornamentation of some spiriferide brachiopods. Palaeontology 19, 767-771.

Brunton, C.H.C. 1984. Silicified brachiopods from the Viséan of County Fermanagh, Ireland (III). Rhynchonellids, Spiriferids and Terebratulids. Bulletin of the British Museum (Natural History), Geology 38, 27-130.

Brunton, C.H.C. 1987. The palaeoecology of brachiopods, and other faunas, of Lower Carboniferous (Asbian) limestones in West Fermanagh. Irish Journal of Earth Sciences 8, 97-112.

Brunton, C.H.C., Alvarez, F. \& MacKinnon, D.I. 1996. Morphological terms used to describe the cardinalia of articulate brachiopods: homologies and recommendations. Historical Biology 11, 9-41. DOI 10.1080/10292389609380533

Brunton, C.H.C. \& Champion, C. 1974. A Lower Carboniferous brachiopod fauna from the Manifold Valley, Staffordshire. Palaeontology 17, 811-840.

BRunTON, C.H.C. \& Cocks, L.R.M. 1996. The classification of the brachiopod order Strophomenida, 47-52. In COPPER, P. \& JIN, J. (eds) Brachiopods: proceedings of the third international brachiopod congress. Balkema, Rotterdam.

Brunton, C.H.C., Lazarev, S.S., Grant, R.E. \& Jin, Y.-G. 2000. Productidina, 424-565. In KAESLER, R.L. (ed.) Treatise on invertebrate paleontology, Part H, Brachiopoda 3 (revised). Geological Society of America \& University of Kansas Press, Boulder \& Lawrence.

Brunton, C.H.C. \& Mason, T.R. 1979. Palaeoenvironments and correlations of the Carboniferous rocks in west Fermanagh, Ireland. Bulletin of the British Museum (Natural History), Geology 32, 91-108.

Brunton, C.H.C. \& Mundy, D.J.C. 1986. Some Dinantian Chonopectinid Productaceans (Brachiopoda) from the British Isles. Proceedings of the Yorkshire Geological Society 46, 1-10. DOI 10.1144/pygs.46.1.1

Brunton, C.H.C., Mundy, D.J.C. \& Lazarev, S.S. 1993. Productellid and plicatiferid (productoid) brachiopods from the Lower Carboniferous of the Craven Reef Belt, North York- shire. Bulletin of the British Museum (Natural History), Geology 49(2), 99-119.

Brunton, C.H.C. \& Tilsley, J.W. 1991. A checklist of brachiopods from Treak Cliff, Derbyshire, with reference to other Dinantian (Lower Carboniferous localities). Proceedings of the Yorkshire Geological Society 48, 287-295.

DOI 10.1144/pygs.48.3.287

CampBell, K.S.W. 1959. The type species of three upper Paleozoic punctate spiriferoids. Palaeontology 1, 351-363.

CARTER, J.L. 1972. Two new genera of lamellose spiriferacean brachiopods. Journal of Paleontology 46, 729-734.

CARTER, J.L. 1999. Tournaisian (early Osagean) brachiopods from a bioherm in the St. Joe Formation near Kenwood, Oklahoma. Annals of Carnegie Museum 68, 91-149.

CARTER, J.L. \& Johnson, J.G. 2006. Spiriferinida, 1877-1937. In KAESLER, R.L. (ed.) Treatise on invertebrate paleontology, Part H, Brachiopoda, 5 (revised). Geological Society of America \& University of Kansas Press, Boulder \& Lawrence.

Carter, J.L., Johnson, J.G., Gourvennec, R. \& Hou, H.-F. 2006. Spiriferida, 1689-1870. In KAESLER, R.L. (ed.) Treatise on invertebrate paleontology, Part H, Brachiopoda, 5 (revised). Geological Society of America \& University of Kansas Press, Boulder \& Lawrence.

CoOper, G.A. \& Muir-Wood, H.M. 1951. Brachiopod homonyms. Journal of the Washington Academy of Sciences 1, 195-196.

DAGYS, A.S. 1972. The occurrence of a Metachoresa in a Triassic spiriferinid. Akademiya nauk SSSR, Sibirskoe otdelenie, Institut geologii i geofiziki, Trudy 111, 34-44. [in Russian]

DAvidson, T. 1858. Palaeontological notes on the Brachiopoda. No. 1. On the genera and subgenera of Brachiopoda that are provided with spiral appendages for the support of the oral arms, and species so constructed, which have been discovered in British Carboniferous strata. Geologist 1, 409-416, $457-472$.

DAVIDSON, T. 1859. British fossil Brachiopoda, vol. 2. Carboniferous, part 5, no. 2, 49-80. Palaeontographical Society Monograph, London.

DAVIDSON, T. 1881. On genera and species of spiral-bearing Brachiopoda from specimens developed by the Rev. Norman Glass. Geological Magazine (New Series, Decade 2) 8, 1-13.

Deline, B., Baumiller, T.K., Kaplan, P., Kowalewski, M. \& HoffMeister, A.P. 2003. Edge-drilling on the brachiopod Perditocardinia cf. P. dubia from the Mississippian of Missouri (USA). Palaeogeography, Palaeoclimatology, Palaeoecology 201, 211-219. DOI 10.1016/S0031-0182(03)00626-6

Demanet, F. 1934. Les brachiopodes du Dinantien de la Belgique. Vol. 1, Atremata, Neotremata, Protremata (pars). Mémoires du Musée royal d'Histoire naturelle de Belgique 61, 1-116.

Demanet, F. 1958. Contribution à l'étude du Dinantien de la Belgique. Mémoires de l'Institut royal des Sciences naturelles de Belgique 141, 1-152.

Fleming, J. 1828. A History of British Animals, Exhibiting the Descriptive Characters and Systematical Arrangement of the Genera and Species of Quadrupeds, Birds, Reptiles, Fishes, Mollusca, and Radiata of the United Kingdom. 565 pp. Bell \& Bradfute \& James Duncan, Edinburgh \& London.

Fürsich, F.T. \& HuRST, J.M. 1974. Environmental factors deter- 
mining the distribution of the brachiopods. Palaeontology 17, 879-900.

Gallwitz, H. 1932. Die Fauna des deutschen Unterkarbons. 3. Teil: 2. Die Brachiopoden, 3. Teil. Die Orthiden, Strophomeniden und Choneten des Unterkarbons (Etrœungt). Abhandlungen der Preussichen Geologischen Landesanstalt (Neue Folge) 141, 75-131.

Garbelli, C., Angiolini, L., Shen, S., Crippa, G., Yuan, D., Bahrammanesh, M., AbBasi, S. \& Birjandi, M. 2014. Additional brachiopod findings from the Lopingian succession of the Ali Bashi Mountains, NW Iran. Rivista Italiana di Paleontologia e Stratigrafia 120, 119-126.

George, T.N. 1931. Ambocoelia Hall and certain similar British Spiriferidae. Quarterly Journal of the Geological Society of London 87, 30-61.

DOI 10.1144/GSL.JGS.1931.087.01-04.05

George, T.N. \& OswaLD, D.H. 1957. The Carboniferous rocks of the Donegal syncline. Quarterly Journal of the Geological Society of London 113, 137-179.

DOI 10.1144/GSL.JGS.1957.113.01-04.07

GoRJAnSKY, V.Y. \& PoPOv, L.E. 1985. The morphology, systematic position, and origin of inarticulate brachiopods with carbonate shells. Paleontologicheskii zhurnal 1985(1), 3-13. [in Russian]

GRANT, R.E. 1972. The lophophore and feeding mechanism of the Productidina (Brachiopoda). Journal of Paleontology 46, 213-248.

GRANT, R.E. 1976. Permian brachiopods from Southern Thailand. Palaeontological Society Memoir 9, 1-269.

GRANT, R.E. 1980. Koskinoid perforations in brachiopod shells: function and mode of formation. Lethaia 13, 313-319. DOI 10.1111/j.1502-3931.1980.tb01056.x

GRAY, J.E. 1840. Synopsis of the contents of the British Museum. Forty-second edition. 370 pp. G. Woodfall, London.

GRunt, T.A. 1986. Classification of brachiopods of the order Athyridida. Akademiya nauk SSSR, Trudy Paleontologicheskogo instituta 215, 1-200.

Hall, J. 1857. Descriptions of new species of Paleozoic fossils from the Lower Helderberg, Oriskany Sandstone, Upper Helderberg, Hamilton and Chemung Groups. New York State Cabinet of Natural History, $10^{\text {th }}$ Annual Report 10, 41-186.

Hall, J. 1860. Observations on Brachiopoda. New York State Cabinet of Natural History, Annual Report 13, 65-75.

HaLl, J. 1861. Descriptions of new species of fossils from the Upper Helderberg, Hamilton, and Chemung groups; with observations upon previously described species. New York State Cabinet of Natural History, Annual Report 14, 99-109.

Hall, J. \& Clarke, J.M. 1890. Extract. Palaeontology of New York, vol. 8, part 1, 120-137, 160. Charles van Benthuysen \& Sons, Albany.

Hall, J. \& Clarke, J.M. 1893. An Introduction to the Study of the Genera of Palaeozoic Brachiopoda. Palaeontology of New York, vol. 8, part 2, 317 pp. Charles van Benthuysen \& Sons, Albany.

Hance, L., Poty, E. \& Devuyst, F.X. 2006. Viséan. Geologica Belgica 9, 55-62.

Harper, D.A.T \& JefFrey, A.L. 1996a. Mid-Dinantian brachiopod biofacies from western Ireland, 427-436. In Strogen, P., Somerville, I.D. \& Jones, G.L. (eds) Recent advances in
Lower Carboniferous geology. Geological Society of London, Special Publication 107.

HaRper, D.A.T \& JEFFrey, A.L. 1996b. The ontogeny of the silicified brachiopod Leptagonia from mid-Dinantian (late Arundian) limestones in western Ireland. Irish Journal of Earth Sciences 15, 77-90.

HavlíčEK, V. 1967. Brachiopoda of the suborder Strophomenidina in Czechoslovakia. Rozpravy Ústředního ústavu geologického 33, 1-235.

Holmer, L.E. \& Popov, L.E. 2000. Lingulida, 32-97. In KAESLER, R.L. (ed.) Treatise on invertebrate paleontology, Part H, Brachiopoda 2 (revised). Geological Society of America \& University of Kansas Press, Boulder \& Lawrence.

Ivanova, E.A. 1972. Main features of spiriferid evolution (Brachiopoda). Paleontologicheskii zhurnal 1972(3), 28-42. [in Russian]

Jux, U. \& Strauch, F. 1966. Die Mitteldevonische brachiopoden-gattung Uncites Defrance 1825. Palaeontographica, Abteilung A 125, 176-222.

KING, W. 1850. A monograph of the Permian Fossils of England. Palaeontographical Society Monograph 3, 1-258.

DE Koninck, L.G. 1842-1844. Description des animaux fossiles qui se trouvent dans le terrain carbonifère de Belgique. 650 pp. Dessain, Liège.

DE KonincK, L.G. 1887. Faune du calcaire carbonifère de la Belgique. Sixième partie. Brachiopodes. Annales du Musée d'Histoire naturelle de Belgique 14, 1-154.

Kunn, O. 1949. Lehrbuch der Paläozoologie. 326 pp. E. Schweizerbart, Stuttgart.

Lee, D.E., Mackinnon, D.I., SmiRnova, T.N., BaKer, P.G., Jin, Y.-G. \& Sun, D.-L. 2006. Terebratulida, 1965-2250. In KAESLER, R.L. (ed.) Treatise on invertebrate paleontology, Part H, Brachiopoda 5 (revised). Geological Society of America \& University of Kansas Press, Boulder \& Lawrence.

LÉVEILLÉ, C. 1835. Aperçu géologique de quelques localités très riches en coquilles sur les frontières de France et de Belgique. Mémoires de la Société géologique de France 2, 29-40.

LEvin, L.A. 2003. Oxygen minimum zone benthos: adaptation and community response to hypoxia. Oceanography and Marine Biology: an Annual Review 41, 1-45.

Macdermot, C.V., Long, C.B. \& Harney, S.J. 1996. A geological description of Sligo, Leitrim and adjoining parts of Cavan, Fermanagh, Mayo and Roscommon, to accompany the Bedrock Geology 1:100,000 Scale Map Series, sheet 7, Sligo Leitrim, with contributions by K. Claringbold, D. Daly, R. Meehan and G. Stanley. 99 pp. Geological Survey of Ireland.

MARCou, J. 1858. Geology of North America, with two reports on the prairies of Arkansas and Texas, the Rocky Mountains of New Mexico and the Sierra Nevada of California. 144 pp. Zürcher and Furrer, Zurich.

Martin, W. 1809. Petrificata Derbiensia; or Figures and Descriptions of Petrefactions Collected in Derbyshire. 28 pp. D. Lyon, Wigan.

Martínez Chacón, M.L. 1979. Braquiópodos Carboníferos de la Cordillera Cantábrica (Orthida, Strophomenida y Rhynchonellida). Memoria del Instituto Geológico y Minero de España 96, 1-291.

Martínez Chacón, M.L. 1997. Braquiópodos silicificados viseenses de Los Santos de Maimona (Badajoz, SO de 
España). Geobios, Mémoire spécial 20, 357-372. DOI 10.1016/S0016-6995(97)80040-X

Martínez Chacón, M.L. \& García-AlCALde, J.L. 1978. La genesis del koskinoide en braquiopodos articulados. Revista de la Facultad de Ciencias, Universidad de Oviedo 17-19, 261-279.

Martínez Chacón, M.L. \& Winkler Prins, C.F. 1977. A Namurian brachiopod fauna from Meré (Province of Oviedo, Spain). Scripta Geologica 39, 1-67.

Martínez Chacón, M.L., Winkler Prins, C.F., Sanz López, J., FerRer, E. \& Magrans, J. 2003. Braquiópodos misisípicos de los alrededores de Barcelona (Cadenas Costeras Catalanas, NE de España). Revista Española de Paleontología 18, 189-204.

MeEk, F.B. 1875. A report on some of the invertebrate fossils of the Waverly Group and coal-measures of Ohio. Geological Survey of Ohio, Report 2, 269-347.

Moore, R.C. 1952. Brachiopods, 197-267. In Moore, R.C., Lalicker, C.G. \& Fischer, A.G. (eds) Invertebrate fossils. 766 pp. McGraw-Hill, New York.

MorRIS, G.P. 1994. Some new Lower Carboniferous cardirinid brachiopods from the Milldale limestones (Visean, Chadian) of North Staffordshire, England. Neues Jahrbuch für Geologie und Paläontologie, Monatshefte 1994, 267-276.

MotTequin, B. 2010. Mississippian (Tournaisian) brachiopods from the Hook Head Formation, County Wexford (south-east Ireland). Special Papers in Palaeontology 84, 243-285.

Mottequin, B. \& Legrand-Blain, M. 2010. Late Tournaisian (Carboniferous) brachiopods from Mouydir (Central Sahara, Algeria). Geological Journal 45, 353-374.

Mottequin, B. \& Sevastopulo, G. 2009. Predatory boreholes in Tournaisian (Lower Carboniferous) spiriferid brachiopods. Lethaia 42, 274-282.

DOI 10.1111/j.1502-3931.2008.00137.x

Muir-Wood, H.M. 1955. A history of the classification of the phylum Brachiopoda. 124 pp. British Museum (Natural History), London.

Muir-Wood, H.M. 1962. On the morphology and classification of the brachiopod suborder Chonetoidea. British Museum (Natural History), London, Monograph 8, 1-132.

Muir-Wood, H.M. \& Cooper, G.A. 1960. Morphology, classification and life habits of the Productoidea (Brachiopoda). Memoir of the Geological Society of America 81, 1-447. DOI 10.1130/MEM81-p1

NoRTH, F.J. 1920. On Syringothyris Winchell and certain Carboniferous Brachiopoda referred to Spiriferina d'Orbigny. Quarterly Journal of the Geological Society of London 76, 162-227. DOI 10.1144/GSL.JGS.1920.076.01-04.06

OrBIGNY, A. D'1847. Considérations zoologiques et géologiques sur les brachiopodes ou palliobranches, parts 1-2. Comptes Rendus Hebdomadaires des Séances de l'Académie des Sciences ( $2^{\text {nd }}$ series) 25, 193-195, 266-269.

Oswald, D.H. 1955. The Carboniferous rocks between the Ox Mountains and Donegal Bay. Quarterly Journal of the Geological Society of London 111, 167-186.

DOI 10.1144/GSL.JGS.1955.111.01-04.09

Paeckelmann, W. 1930. Die fauna des deutschen Untercarbons. Die Brachiopoden, I: die Orthiden, Strophomeniden und Choneten des mittleren und oberen Unterkarbons. Abhandlungen der Königliche-Preussische Geologische Landesanstalt, Neuе Folge 122, 143-326.

Pakhnevich, A.V. 2013. Revision of the Superfamily Rhynchoporoidae Muir-Wood, 1955. Paleontological Journal 47, 36-43. DOI 10.1134/S0031030112120064

Payne, J.L., McClain, C.R., Boyer, A.G., Brown, J.H., Finnegan, S., Kowalewski, M., Krause, R.A. Jr., Lyons, S.K., McShea, D.W., Novack-GotTshall, P.M., Smith, F.A., Spaeth, P., Stempien, J.A. \& WAng, S.C. 2011. The evolutionary consequences of oxygenic photosynthesis: a body size perspective. Photosynthesis Research 107, 35-57.

DOI 10.1007/s11120-010-9593-1

Pérez-Huerta, A. 2004. New Carboniferous brachiopods from the eastern Great Basin, Nevada, USA: implications for loop ontogeny and evolution in Late Palaeozoic terebratuloids. Palaeontology 47, 1519-1537.

DOI 10.1111/j.0031-0239.2004.00427.x

Pérez-Huerta, A. \& Sheldon, N.D. 2006. Pennsylvanian sea level cycles, nutrient availability and brachiopod paleoecology. Palaeogeography, Palaeoclimatology, Palaeoecology 230, 264-279. DOI 10.1016/j.palaeo.2005.07.020

PhILLIPS, J. 1836. Illustrations of the geology of Yorkshire, Part 2. The mountain limestone district. 253 pp. John Murray, London.

Phillips, J. 1841. Figures and descriptions of the Palaeozoic fossils of Cornwall, Devon, and West Somerset. 231 pp. Longman, Brown, Green and Longmans, London.

PIRLET, H. 1967. Nouvelle interprétation des carrières de Richelle; le Viséen de Visé. Annales de la Société géologique de Belgique 90, B299-328.

Pоту, E. 1982. Paleokarsts et brèches d'effondrement dans le Frasnien moyen des environs de Visé. Leur influence dans la paléogéographie dinantienne. Annales de la Société géologique de Belgique 105, 315-337.

Rachebeuf, P.R. 2000. Chonetidina, 362-423. In Kaesler, R.L. (ed.) Treatise on invertebrate paleontology, Part $H$, Brachiopoda 2 (revised). Geological Society of America \& University of Kansas Press, Boulder \& Lawrence.

Río García, L.M. 2002. Braquíopodos moscovienses (Chonetidina y Orthotetida) de los Paquetes Improductivos de la Cuenca Carbonífera Central de Asturias ( $\mathrm{N}$ de España). Revista Española de Paleontología 17, 137-155.

Sarycheva, T.G. \& Sokolskaya, A.N. 1959. On the classification of pseudopunctate brachiopods. Akademiia nauk SSSR, Doklady 125, 181-184. [in Russian]

SAVAGE, N.M. 2002. Rhynchoporoidea, 1232-1235. In KAESLER, R.L. (ed.) Treatise on invertebrate paleontology, Part H, Brachiopoda, 4 (revised). Geological Society of America \& University of Kansas Press, Boulder \& Lawrence.

Savage, N.M., Manceñido, M.O., Owen, E.F., Carlson, S.J., Grant, R.E., Dagys, A.S. \& Sun, D.-L. 2002. Rhynchonellida, 1027-1376. In KAESLER, R.L. (ed.) Treatise on invertebrate paleontology, Part H, Brachiopoda 4 (revised). Geological Society of America \& University of Kansas Press, Boulder \& Lawrence.

Schuchert, C. 1929. Classification of brachiopod genera, fossil and Recent, 10-25. In PoMPeCKJ, J.F. (ed.) Fossilium Catalogus, Volume 1: Animalia. 140 pp. W. Junk, N.V., Berlin.

Schuchert, C. \& Cooper, G.A. 1932. Brachiopod genera of the 
suborders Orthoidea and Pentameroidea. Memoirs of the Peabody Museum of Natural History 4, 1-270.

Schuchert, C. \& LeVene, C.M. 1929. Brachiopoda (Generum et Genotyporum Index et Bibliographia), 1-140. In PoMPECKJ, J.F. (ed.) Fossilium Catalogus, Volume 1: Animalia. 140 pp. W. Junk, N.V., Berlin.

Sevastopulo, G.D. 2002. Fossil 'Lilies of the ocean' and other echinoderms from Carboniferous rocks of Ireland. John Jackson Memorial lecture 2002. The Royal Dublin Society Occasional Papers in Science 25, 1-15.

Sevastopulo, G.D. 2008. Paleobiology of Carboniferous microcrinoids, 53-69. In Ausich, W.I. \& WeBster, G.D. (eds) Echinoderm Paleobiology. Indiana University Press, Bloomington.

Sevastopulo, G.D. \& Wyse Jackson, P.N. 2009. Carboniferous: Mississippian (Tournaisian and Viséan), 215-268. In HoLLAND, C.H. \& SANDERS, I.S. (eds) The Geology of Ireland. $2^{\text {nd }}$ revised edition. Academic Press, Dunedin.

Sokolskaya, A.N. 1950. Chonetidae of the Russian Platform. Akademiia nauk SSSR, Trudy Paleontologicheskogo instituta 27, 1-108. [in Russian]

Stehl, F.G. 1954. Lower Leonardian Brachiopoda of the Sierra Diablo. Bulletin of the American Museum of Natural History 105, 257-358.

Sun, Y.-L. \& BALIŃSKi, A. 2008. Silicified Mississippian brachiopods from Muhua, southern China: Lingulids, craniids, strophomenids, productids, orthotetids, and orthids. Acta Palaeontologica Polonica 53, 485-524. DOI 10.4202/app.2008.0309

SUN, Y.-L. \& BALIŃSKI, A. 2011. Silicified Mississippian brachiopods from Muhua, southern China: Rhynchonellides, athyridides, spiriferides, spiriferinides, and terebratulides. Acta Palaeontologica Polonica 56, 793-842. DOI 10.4202/app.2010.0106

ThaYer, C.W. 1986. Are brachiopods better than bivalves? Mechanisms of turbidity tolerance and their interaction with feeding in articulates. Paleobiology 12, 161-174.

Thomas, G.A. 1958. The Permian Orthotetacea of Western Australia. Bureau of Mineral Resources, Geology and Geophysics, Bulletin 39, 1-159.

Thomson, J.A. 1926. A revision of the subfamilies of the Terebratulidae (Brachiopoda). Annals and Magazine of Natural History (series 9) 18, 523-530.
TomašovÝch, A. 2006. Brachiopod and bivalve ecology in the Late Triassic (Alps, Austria): onshore-offshore replacements caused by variations in sediment and nutrient supply. Palaios 21, 344-368. DOI 10.2110/palo.2005.P05-53e

Vogel, K. 1975. Das filter-feeding bei Spiriferida. Lethaia 8, 231-240. DOI 10.1111/j.1502-3931.1975.tb00927.x

WaAgen, W.H. 1883. Salt Range fossils, Part 4 (2), Brachiopoda. Palaeontologia Indica (Series 13) 4, 391-546.

WaAgEn, W.H. 1884. Salt Range fossils, Part 4 (2), Brachiopoda. Palaeontologia Indica (Series 13) 4, 547-610.

WAagen, W.H. 1885. Salt Range fossils, Part 4 (2), Brachiopoda. Palaeontologia Indica (Series 13) 4, 729-770.

Waterhouse, J. B. 1975. New Permian and Triassic brachiopod taxa. University of Queensland, Department of Geology, Papers 7(1), 1-23.

Weller, S. 1914. The Mississippian Brachiopoda of the Mississippi Valley Basin. Illinois State Geological Survey, Monograph 1, 1-509.

WhITFIELD, R.P. 1890. Description of a new genus of inarticulate brachiopodous shell. American Museum of Natural History, Bulletin 3, 121-122.

Williams, A. 1953. The classification of the strophomenoid brachiopods. Washington Academy of Sciences Journal 43, $1-13$.

Williams, A. \& Brunton, C.H.C 1993. Role of the shell structure in the classification of the orthotetidine brachiopods. Palaeontology 36, 931-966.

Williams, A. \& Brunton, C.H.C. 2000. Orthotetidina, 644-681. In KAESLER, R.L. (ed.) Treatise on invertebrate palaeontology, Part H, Brachiopoda 3 (revised). Geological Society of America \& University of Kansas Press, Boulder \& Lawrence.

Williams, A., Carlson, S.J., Brunton, C.H.C., Holmer, L.E. \& Popov, L.E. 1996. A supra-ordinal classification of the Brachiopoda. Philosophical Transactions of the Royal Society of London, Series B 351, 1171-1193.

DOI 10.1098/rstb.1996.0101

Williams, A. \& Harper, D.A.T. 2000. Orthida, 714-846. In KAESLER, R.L. (ed.) Treatise on invertebrate palaeontology, Part H, Brachiopoda 3 (revised). Geological Society of America \& University of Kansas Press, Boulder \& Lawrence.

ZingULA, R.P. 1968. A new breakthrough in sample washing. Journal of Paleontology 42, 1092. 